\title{
Palaeoenvironmental reconstruction of Bathonian (Middle Jurassic) ore-bearing clays at Gnaszyn, Kraków-Silesia Homocline, Poland
}

\author{
PRZEMYSŁAW GEDL ${ }^{1}$, ANDRZEJ KAIM ${ }^{2}$, PAULINA LEONOWICZ ${ }^{3}$, ANDRZEJ BOCZAROWSKI ${ }^{4}$, \\ TERESA DUDEK ${ }^{1}$, MARIUSZ KĘDZIERSKI ${ }^{5}$, JAN REES ${ }^{6}$, JOLANTA SMOLEN' ${ }^{7}$, PATRYCJA \\ SZCZEPANIK $^{5}$, PRZEMYSLAW SZTAJNER ${ }^{8}$, MAGDA WITKOWSKA $^{5}$ AND JADWIGA ZIAJA ${ }^{9}$
}

1Institute of Geological Sciences, Polish Academy of Sciences, Senacka 1, 31-002 Kraków, Poland. E-mails:ndgedl@cyf-kr.edu.pl; tereska_wing@yahoo.co.uk

${ }^{2}$ Institute of Paleobiology, Polish Academy of Sciences, Twarda 51/55, PL-00-818 Warszawa, Poland. E-mail:kaim@twarda.pan.pl

${ }^{3}$ Institute of Geology, University of Warsaw, Żwirki i Wigury 93, 02-089 Warszawa, Poland. E-mail:Paulina.Leonowicz@uw.edu.pl

${ }^{4}$ Faculty of Earth Sciences, University of Silesia, Będzinska 60, 41-200 Sosnowiec, Poland. E-mail: a.boczarowski@chello.pl

${ }^{5}$ Institute of Geological Sciences, Jagiellonian University, Oleandry Str. 2a, 30-063 Kraków.

E-mails:mariusz.kedzierski@uj.edu.pl;szczep@ing.uj.edu.pl;magda.witkowsky@interia.pl ${ }^{6}$ Soldattorpet 48, SE-653 50 Karlstad, Sweden.E-mail: janrees71@gmail.com

${ }^{7}$ Polish Geological Institute, Rakowiecka 4,00-975 Warszawa, Poland. E-mail: jolanta.smolen@pgi.gov.pl ${ }^{8}$ Institute of Marine Sciences, Geology and Paleogeography Department, University of Szczecin, Mickiewicza 18,70-383 Szczecin, Poland. E-mail: sztajner@univ.szczecin.pl

${ }^{9}$ W. Szafer Institute of Botany, Polish Academy of Sciences, Lubicz 46, 31-512 Kraków, Poland. E-mail:J.Ziaja@botany.pl

\section{ABSTRACT:}

Gedl, P., Kaim, A., Leonowicz, P., Boczarowski, A., Dudek, T., Kędzierski, M., Rees, J., Smoleń, J., Szczepanik, P., Sztajner, P., Witkowska, M. and Ziaja, J. 2012. Palaeoenvironmental reconstruction of Bathonian (Middle Jurassic) ore-bearing clays at Gnaszyn, Kraków-Silesia Homocline, Poland. Acta Geologica Polonica, 62 (3), 463-484. Warszawa.

Multidisciplinary studies of the Middle-Upper Bathonian ore-bearing clays at Gnaszyn revealed variable palaeoenvironmental conditions during the deposition of this seemingly monotonous sequence. We interpret the conditions in the bottom environment and the photic zone, and also evaluate the influence of the adjacent land areas, based on sedimentology, geochemistry, sporomorphs and palynofacies composition, benthic (foraminifera, gastropods, bivalves, scaphopods, echinoderms), planktonic (calcareous nannoplankton, dinoflagellate cysts), and nektonic (sharks) fossils. The Gnaszyn succession originated relatively close to the shore, within reach of an intense supply of terrestrial fine clastic and organic particles. The latter are mainly of terrestrial origin and range from 1.5 to $2.5 \mathrm{wt} \%$. The precise water depth is difficult to estimate but most likely ranges from several tens of metres to a few hundred metres. All fossil groups show minor changes throughout the succession. As the climate seems to have been quite stable during this period we consider sea-level fluctuations to have been the main factor responsible for the changes. The terrestrial input, including freshwater and land-derived clastic and organic particles (sporomorphs and cuticles), increased during periods of sea-level lowstand. As a consequence, stress conditions (lower salinity, higher nutrient availability, lower water transparency) in the photic zone caused blooms of opportunistic planktonic taxa. Furthermore, a faster sedimentation rate led to oxygen depletion and deterioration of the living conditions in the bottom environment due to an increased accu- 
mulation of organic matter. As a result, the benthic biota became taxonomically impoverished and commonly dominated by juvenile forms. During periods of high sea level, the source areas were shifted away from the basin, resulting in a decrease in the terrestrial influx, increase in the salinity of surface waters, the appearance of more diverse phytoplankton assemblages, a lower sedimentation rate, and an improvement of living conditions at the bottom.

Key words: Bathonian; Jurassic; Palaeoenvironment; Ore-bearing clays; Poland.

\section{INTRODUCTION}

Our studies of the Middle-Upper Bathonian (Middle Jurassic) ore-bearing clays cropping out at Gnaszyn (Text-figs 1,3) are an attempt to reconstruct the palaeoenvironmental conditions prevailing during their formation (Gedl et al. 2003, 2006). The model we propose is based on a multidisciplinary approach, including studies of several fossil (mainly microfossil) groups, which characterize conditions in the water
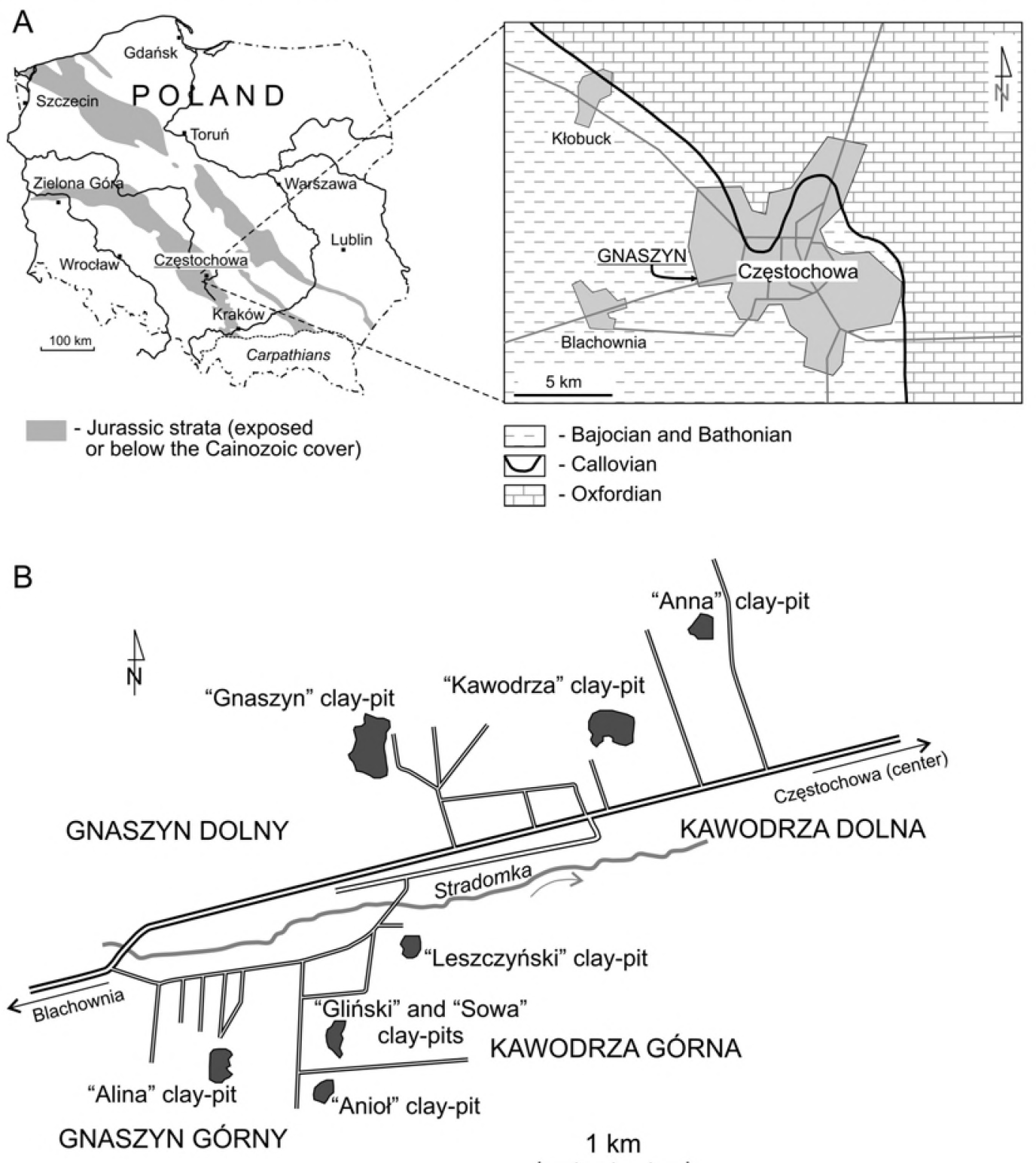

Text-fig. 1. Simplified geological map of the Częstochowa town and its vicinity (A - after Majewski 2000) and location of the Gnaszyn clay-pit (B - after Matyja and Wierzbowski 2003) 
column and bottom environment, coupled with studies showing the conditions in the neighbouring land areas. To support our model, we also carried out mineralogical and geochemical investigations - including trace element composition - as well as a detailed sedimentological study. With the exception of the sedimentological analysis, all of the studies were based on the same set of samples. This approach allows a precise reconstruction of the relationships between particular fossil groups, as well as the sedimentological and geochemical record.

This final paper summarises the interpretations of the various fossil groups and the results of the geochemical, mineralogical and sedimentological studies, combining the results into a synthetic interpretation of the Bathonian environments at Gnaszyn.

\section{PALAEOGEOGRAPHY OF THE BATHONIAN EPICONTINENTAL BASIN IN POLAND}

The Middle Jurassic epicontinental Polish Basin was formed by a transgression that started during the Early Aalenian (Dayczak-Calikowska 1997). Initially, the epicontinental marine basin was limited to a narrow belt (the so-called Polish Trough) extending north-west to south-east and bordered by the land areas of the Bohemian Massif (the so-called SudetySilesia and Małopolska lands) to the south-west, and Fennosarmatia (Belarussian High and Ukrainian Shield) to the north-east (e.g., Ziegler 1988; Dadlez 1989; Dayczak-Calikowska 1997; Text-fig. 2A). Subsequent transgressive pulses from the Tethyan Ocean led to a gradual increase in size of the marine basin. During the Middle Bathonian (the period of sedimentation of the main portion of the Gnaszyn succession) the emerged area of the Sudety-Silesian Land withdrew to the south-west, and the Małopolska Land became largely flooded, with the more elevated areas forming islands (Text-fig. 2B). The depositional setting of Gnaszyn was thus located on the south-western periphery of the marine basin, relatively close to the Sudety-Silesia Land, which was a main source area for terrestrial influx into the basin; the land-mass of the more remote Fennosarmatia had presumably a smaller influence on sedimentation into the basin in the neighbourhood of Gnaszyn. Later, during the late Bathonian, a strong transgressive pulse led to further extension of the marine basin, which covered almost the entire area of the present day territory of Poland, resulting in the cessation of deposition of the ore-bearing clays (Dayczak-Calikowska and Moryc 1988; Dayczak-Calikowska 1997).

\section{RESULTS}

In this chapter brief outlines are given of the results of the individual investigations presented in this thematic volume; these are summarized in Text-figs 4-6.

\section{Sedimentology}

The Gnaszyn succession consists chiefly of muds classified as silty clays, clayey silts and occasionally sand silt-clays (sensu Shepard 1954) (Leonowicz 2012, this issue). The lowest content of clay, coinciding with the highest content of sand, falls into two intervals: between the $\mathrm{N}$ and $\mathrm{O}$, and below the $\mathrm{S}$ siderite horizons. The highest content of clay (and the lowest content of sand) falls in both sections in the interval $1-4 \mathrm{~m}$ above and about $1 \mathrm{~m}$ below the P siderite horizon.

The original sedimentary structures, mostly obliterated by strong bioturbation, include indistinct horizontal bedding, subtle, non-continuous horizontal lamination and lenticular concentrations of shell detritus and very fine sand, interpreted as storm event deposits. The trace fossil association is of low diversity and consists of Chondrites, Trichichnus, pyritized burrows, Palaeophycus, Planolites, Taenidium and Thalassinoides. The highest diversity occurs in the lower part of the section, below the $\mathrm{O}$ concretion level. Above it (i. e. in the Morrisi and Bremeri ammonite zones), the trace fossil association is restricted almost exclusively to Chondrites, Trichichnus and pyritized burrows, accompanied by less common Palaeophycus.

The Gnaszyn succession was deposited in the offshore zone, below the fair-weather wave base, with the seafloor affected by storm-generated offshore flows. The reason for the lateral variability in the grain size composition of the muds was the lack of uniform grain size distribution within the suspension clouds. Vertical changes in lithology can reflect different processes in the hinterland and in the sedimentary basin; a credible explanation of this variation remains elusive pending broader palaeogeographical investigations.

The ichnofossil distribution indicates well-ventilated bottom waters and dysoxic conditions prevailing mainly within the sediment. However, the oxygenation of the bottom water was unstable. The interval above the $O$ siderite horizon was deposited during an oxygen-depleted period compared to the interval below. Enhanced oxygenation of the bottom layer could be linked with more accentuated storm activity.

\section{Siderite concretions}

Witkowska (2012, this issue) distinguished: (1) 


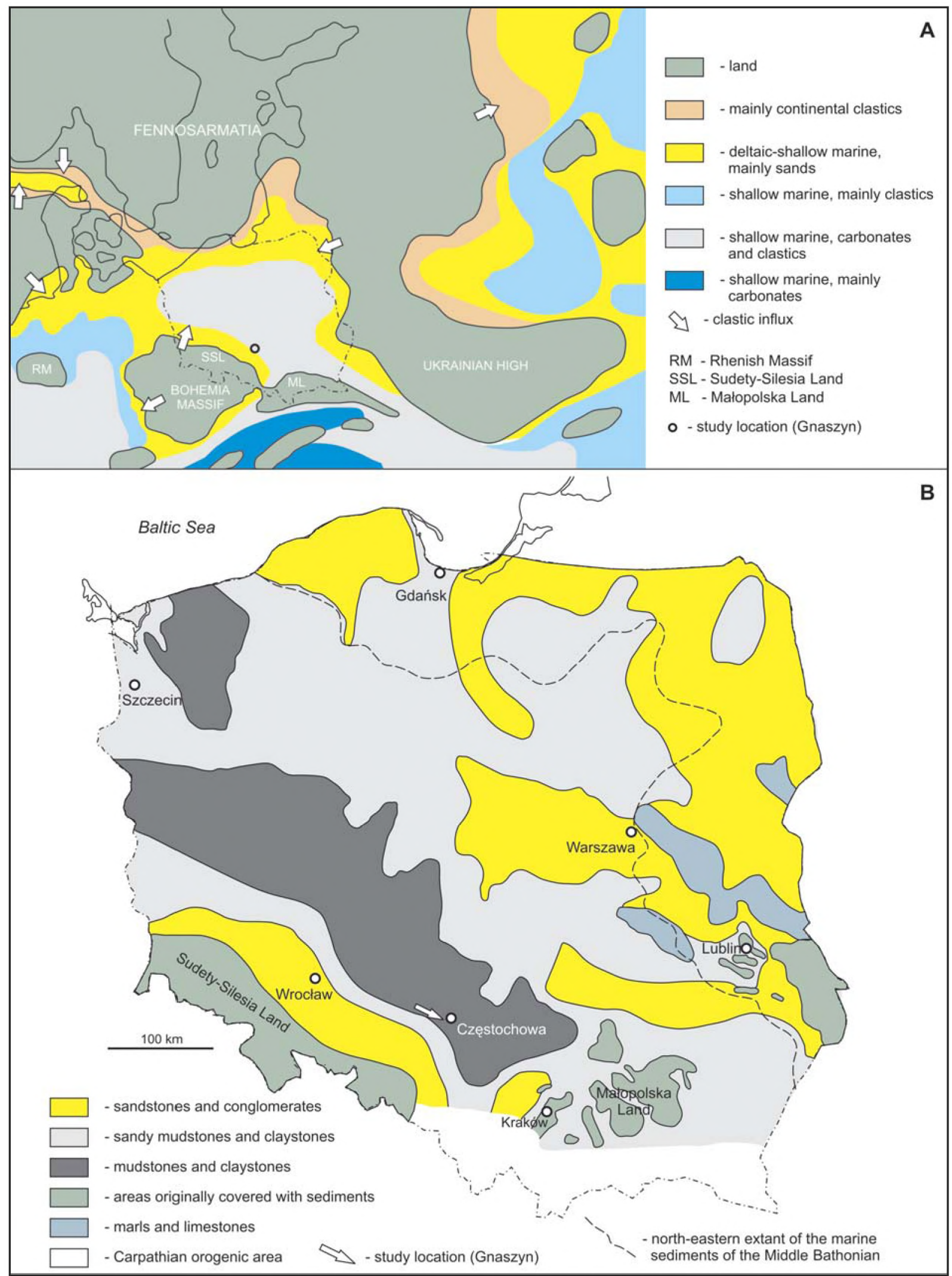

Text-fig. 2. Position of study area. (A) palaeogeographic map of central Europe during Bajocian-Bathonian (from Ziegler 1988); and (B) palaeogeographic map of Poland during Middle and Late Bathonian (Morrisi-Discus ammonite zones; from Dayczak-Calikowska 1997) 


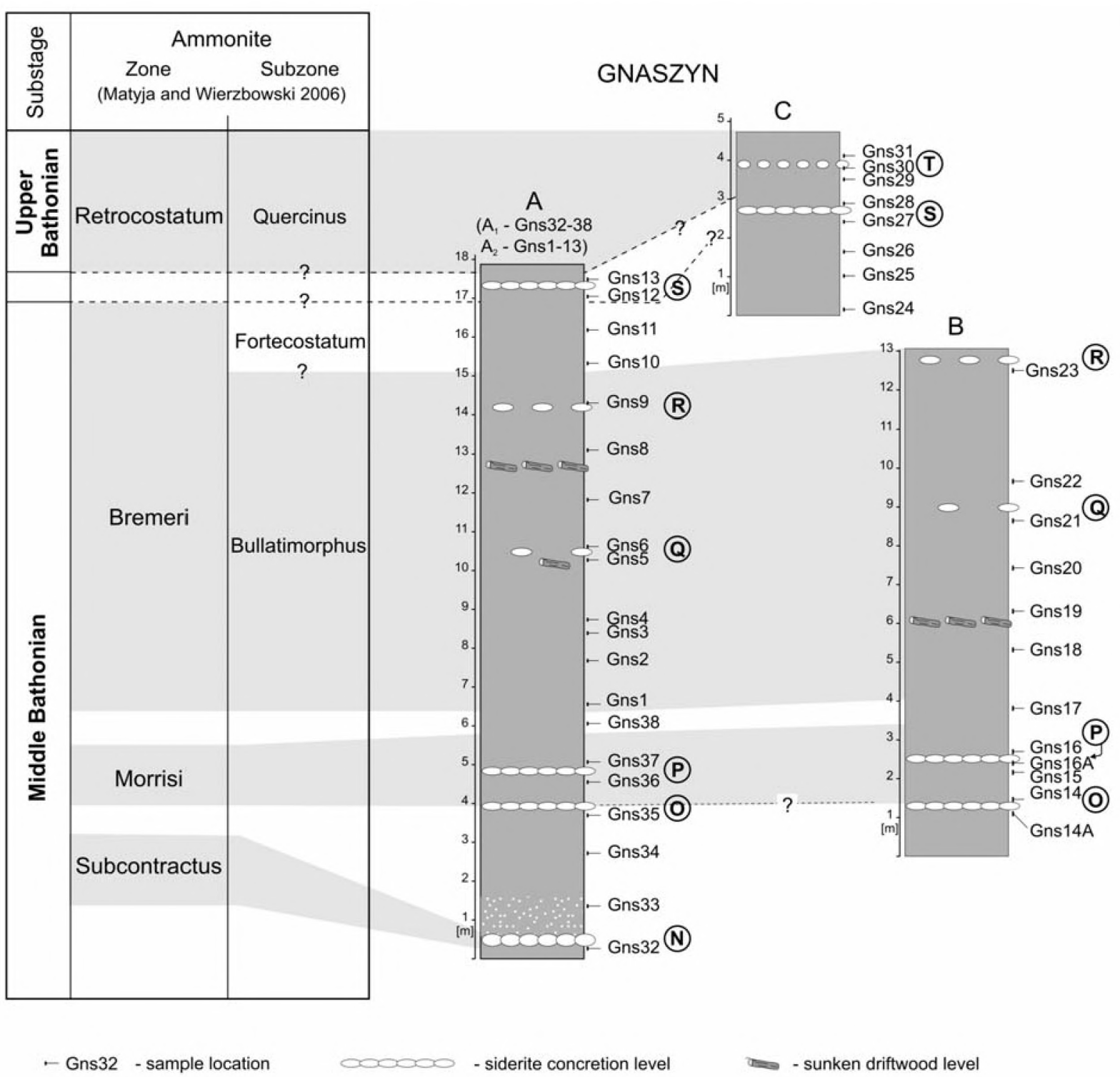

(N) - abbreviation of concretion level

Text-fig. 3. Lithological logs of the studied sections of the ore-bearing clays at Gnaszyn with sample positions indicated (by P. Gedl)

siderite and (2) phosphate-siderite types of concretions. According to her, the formation of concretions started during early diagenesis of the ambient sediments. The presence of siderite indicates that the concretions precipitated in anaerobic conditions as siderite is stable in low values of Eh and high $\mathrm{pCO}_{2}$. Its precipitation also requires a high concentration of dissolved iron ion $\left(\mathrm{Fe}^{2+}\right)$ and bicarbonate ions $\left(\mathrm{HCO}_{3}^{-}\right)$, and an absence of sulphide ions $\left(\mathrm{HS}^{-}\right)$.

Periods with better oxygenation during the deposition of the concretion host sediment favoured more intensive bioturbation of these layers. Bioturbation changed the depth-distribution and evoked redistribu- tion of iron oxides, more reactive organic matter, and sulphide ions in the sediment column, causing greater availability of the first two while limiting the availability of the last deeper in the sediment column. These conditions favoured bacterial decomposition in the iron reduction zone and the precipitation of siderite there. An important environmental factor necessary for siderite formation was an ubiquity of organic matter. The microbial decomposition of the latter in reducing conditions generated $\mathrm{CO}_{2}$, which reduced the iron oxide $\left(\mathrm{Fe}^{3+}\right)$ stable mineral phases into the reduced iron ion $\left(\mathrm{Fe}^{2+}\right)$ necessary for siderite precipitation. This supports an organic origin of the siderite in 
the concretions from the Częstochowa ore-bearing clays, as previously suggested by Witkowska (2005).

The appearance of iron carbonate concretion horizons in the Gnaszyn succession therefore reflects specific conditions involving equilibrium of the main factors controlling the siderite precipitation. It seems that the formation of concretions took place in the redox zone in the sediment between the oxygenated and bioturbated surface zone and the deeper anaerobic zone. The conditions favouring formation of the concretions in this zone remained stable because of the significantly reduced sedimentation rate.

\section{Geochemistry}

The geochemistry of the Gnaszyn succession was studied by Szczepanik (2006) and Szczepanik et al. (2007). They determined the content of major (Al, Ca, $\mathrm{Mg}, \mathrm{Na}, \mathrm{K}, \mathrm{Ti}, \mathrm{Fe}, \mathrm{P})$ and trace $(\mathrm{Mn}, \mathrm{Cr}, \mathrm{Rb}, \mathrm{Sr}, \mathrm{Y}, \mathrm{Nb}$, $\mathrm{Cu}, \mathrm{Zn}, \mathrm{Pb}, \mathrm{Co}, \mathrm{Ni}, \mathrm{V}$ and REE) elements. Subsequently, they calculated selected geochemical parameters for palaeoenvironmnetal interpretations, including $\mathrm{C} / \mathrm{S}, \mathrm{U} / \mathrm{Th}, \mathrm{V} / \mathrm{Cr}, \mathrm{V} / \mathrm{Ni}+\mathrm{V}, \mathrm{Ni} / \mathrm{Co}, \mathrm{Cu}+\mathrm{Mo} / \mathrm{Zn}$. Moreover, Szczepanik et al. (2007) determined total organic carbon (TOC) and total sulphur content, and the carbon stable isotope $\left(\delta^{13} \mathrm{C}\right)$ values in the organic matter.

TOC contents of the Gnaszyn samples range from 1.5 through 2.5 wt $\%$. Selected samples, which were analysed by Rock-Eval pyrolysis, revealed very low values of the hydrogen index (between 11 and $34 \mathrm{mg}$ $\mathrm{HC} / \mathrm{g}$ TOC) and oxygen index (between 40 and 157 $\mathrm{mg} \mathrm{CO} / \mathrm{g}$ TOC. These data were interpreted as indicative for kerogen type III and/or IV (Szczepanik et al. 2007, fig. 3), which is typical of organic matter of terrestrial origin (mainly plant tissue). A terrigenous source of the overwhelmingly organic matter from Gnaszyn was also inferred on the basis of the carbon stable isotope $\left(\delta^{13} \mathrm{C}\right)$ values, which in the studied samples oscillated between -23.3 and $-24.4 \%$ PDB (Szczepanik et al. 2007, table 1), these values being characteristic of terrestrial organic matter, possibly with only a minor admixture of marine organic matter.

Interpretation of other geochemical parameters (e. g., TOC-Fe_S, V/Cr, Ni/Co, U/Th) led Szczepanik et al. (2007) to conclude that the sediments in Gnaszyn succession were deposited in a normal marine environment under relatively well oxygenated (oxic to suboxic) bottom water conditions.

Szczepanik et al. (2007) noted that the values of all the geochemical parameters were generally stable within the Gnaszyn succession, showing only subtle fluctuations that did not significantly influence their palaeoenvironmental interpretation.

\section{Mineralogy}

The mineral composition of the Gnaszyn succession is generally uniform (Dudek 2012, this issue). Quartz, together with K-feldspar and plagioclase, accounts for about $50 \mathrm{wt} \%$ of the total mineral composition. Salts (calcite, gypsum, and anhydrite) and pyrite add up to about $10 \mathrm{wt} \%$. However, samples from the lowermost part of the succession (samples Gns32 to Gns37) contain on average more quartz (about $60 \mathrm{wt} \%$ ) than the remaining samples (40-50 $w t \%$ ). Quartz-enriched levels (above 50\% wt \%) are also shown in samples Gns11, Gns26, Gns27 and Gns31. The clay is dominated by illite, which alone accounts for about $20 \mathrm{wt} \%$ of the total mineral content. Kaolinite amounts to usually $<10 \mathrm{wt} \%$ and chlorite and glauconite occur in subordinate quantities.

The apparent dominance of illite over kaolinite in the Gnaszyn succession indicates prevailing mechanical weathering of the rocks in the source area, which is typical of temperate, cold and dry climatic conditions (Dudek 2012, this issue). Negligible amounts of smectite indicate very little (if any) volcanogenic input. The abundance of quartz, feldspars, illite and kaolinite, which together account for over $80 \mathrm{wt} \%$ of the total mineral composition of the rocks, indicates shales, schists, mudstones, sandstones, and possibly magmatic and metamorphic rocks of felsic composition (granite, gneiss) as the most likely source rock types. The palaeobathymetry of the basin can be defined as 60-1000 m on the presence of glauconite (if authigenic), while the occurrence of calcite implies rather shallow waters.

Pyrite, which is a common mineral in the Gnaszyn succession, occurs both within the sediment and in fossils (Szczepanik 2006; Szczepanik et al. 2007). However, it is mainly associated with the latter, where it encrusts the hard parts or fills voids within the skeletons (no replacements by pyrite were observed). Pyritized trace fossils are also common. In the host sediment, pyrite occurs in form of framboids, euhedra, micronodules and polyframboids. No evident differences in quantitative and qualitative distribution of pyrite within the Gnaszyn succession have been observed.

The pyrite framboids in the sediment range in size from 5 to $25 \mu \mathrm{m}$, occasionally reaching $50 \mu \mathrm{m}$. This indicates that pyrite in the sediment was not formed in an euxinic water column (Szczepanik 2006; Szczepanik et al. 2007).

\section{Palynofacies and sporomorphs}

Palynological organic matter in all the samples from the Gnaszyn succession consists chiefly of ter- 
restrial elements (Gedl and Ziaja 2012, this issue). Marine palynomorphs (mainly dinoflagellate cysts), although present in each sample, occur subordinately. The proportions of particular palynofacies elements show some fluctuations in the vertical succession. Black phytoclasts, i.e. the elements that usually dominate in offshore palynofacies, are most frequent in the lower (Morrisi ammonite Zone) and uppermost part (Retrocostatum Zone) of the Gnaszyn succession. These intervals also contain relatively more common dinoflagellate cysts. They also frequently occur in samples directly below concretion horizons. Cuticle remains occur most frequently in the middle part of the succession (Bremeri Zone, especially in its upper part) and in the basal interval between the $\mathrm{N}$ and $\mathrm{O}$ concretion levels. This frequent appearance of cuticle remains may be related to increased influx of terrestrial organic matter from surrounding land areas. A fall in sea level would increase drainage on the neighbouring land leading to a higher influx of land-derived vascular plant remains.

This hypothesis is supported by the results of sporomorph analysis (Gedl and Ziaja 2012, this issue). Comparison of the ratios of particular sporomorph eco-groups (SEG) shows fluctuations in sea level during the deposition of the Gnaszyn succession. The Upland/Lowland SEGs ratio is highest in the lower part of the succession (Subcontractus-lower part of Bremeri zones), declines higher up to the top of the Bremeri Zone, and increases again in the topmost part of the succession (Retrocostatum Zone). An inverse pattern is shown by the Lowland/Coastal+Tidally-influenced SEGs ratio, which is highest in the middle part of the succession (Bremeri Zone). Both proxies may be indicative of sea-level fluctuations: marine water covers the lowland coast area during periods of higher sea level, thereby limiting the vegetation of this setting (Lowland SEG). Simultaneously, the ratio of sporomorphs produced by vegetation growing in the hinterland (Upland SEG) to sporomorphs produced by vegetation occupying the coastal area (Coastal+Tidallyinfluenced SEGs) increases.

\section{Foraminifera}

Two basic types of foraminiferal assemblages (I and II), characterized by different ratios of calcareous and agglutinated foraminifera and their morphogroups content were distinguished (Smolen 2012, this issue).

Type I assemblages are characterized by a low diversity of calcareous benthic foraminifera, which represent about $80 \%$ of the entire association, and by mass occurrences of the genus Epistomina, especially
Epistomina nuda, which in some samples constitutes $70 \%$ of the whole foraminiferal assemblage. Epistomina nuda is relatively small, 100 to about $200 \mu \mathrm{m}$ in size. Agglutinated foraminifera constitute roughly $20 \%$ of the association. These assemblages occur between levels with concretion horizons (samples Gns17 and Gns18-22). The presence of type I assemblages suggests a low oxygen content in both sediment and bottom waters and a higher sedimentation rate.

Type II assemblages are characterized by higher taxonomic diversity. Although likewise dominated by calcareous benthic species, they also contain diverse assemblages belonging to the family Ceratobuliminidae, and frequent agglutinated foraminifers, which reach up to $30 \%$ of the assemblage. This biofacies characterizes sediments hosting concretion horizons, best seen in samples Gns35-37, Gns14A-16, Gns1213 , Gns23 and Gns28. The intervals with type II assemblages were characterized by a slower sedimentation rate, well oxidized and mixed bottom waters, and a sufficient food supply.

\section{Gastropods}

Gastropods from the Gnaszyn succession are moderately common and of low diversity, except for the assemblages associated with sunken driftwood (Kaim 2011). The fauna is dominated by micromorphic forms, represented mostly by juveniles or larval shells. The only large gastropods are infrequent pleuromariids usually found in the vicinity of concretion horizons.

The distribution of gastropod shells is highly uneven throughout the Gnaszyn succession. This, however, may partly be due to postdepositional factors like early diagenetic dissolution of aragonite shells or weathering processes. Gastropods are rare and poorly preserved in the intervals with concretion horizons, and their frequency increases in the muddy intervals (Kaim 2012, this issue).

The presence of gastropods throughout the Gnaszyn succession indicates relatively well-oxygenated bottom waters. The lack of adult stages (except for the uppermost, T concretion horizon) suggests possible oxygen deficiency near the sediment-water interface and/or fluctuations in oxygen content. Other important factors that controlled the distribution of gastropods in Gnaszyn section seem to have been food availability and type of substratum. The sea bottom was presumably soft during most of the time. As most of the gastropods found in Gnaszyn probably could not live on a soft bottom, they utilised secondary substrata. Intervals with concretion horizons are relatively 
enriched in species of cerithiids, rissoids, aporrhaids, and eucyclids, i. e., taxa that could live on a soft sediment surface, but occurring in larger number only during decreases in the sedimentation rate, allowing microbial films and epigrowths to develop. The other gastropods, especially the cylindrobullinids (Sinuarbullina) and mathildids (Mathilda) dominating in muddy intervals, are known to prey on sedentary organisms, being thus able to flourish when the appropriate prey is present. Eudaronia occurs consistently throughout the succession, suggesting a relatively deep water setting.

\section{Bivalves and scaphopods}

Twelve bivalve families and four morphological groups of scaphopods were recognised in the succession (Kaim and Sztajner 2012, this issue). The bivalves are mostly juveniles. Adult or adolescent specimens, of both bivalves and scaphopods, were found only in the upper part of the succession (samples Gns27-28). Some parallelism in the distribution pattern of bivalves and scaphopods was recognised. Both groups reach their highest taxonomic diversity in the intervals with concretion horizons.

The continuous presence of scaphopods suggests that the bottom waters were well-oxygenated throughout the whole period of deposition of the Gnaszyn succession. Variability in bivalve and scaphopod distribution may be explained by variable sediment/water conditions and, possibly, by oxygen fluctuation in the sediment. The middle part of the succession reflects soft-bottom conditions favourable for nuculoids and Laevidentalium-type scaphopods. The clays in the upper and lower parts of the succession, with concretion horizons, formed during periods of firmer bottom condition, perhaps due to a slower sedimentation rate, favourable for more diverse bivalve and scaphopod biota. Enrichment in adult molluse specimens in the intervals with concretion horizons also indicates a slower sedimentation rate and better living conditions. In places, large shells of Pholadomya and Pinna occur in life position, suggesting instant burial.

\section{Echinoderms}

The Gnaszyn succession contains large numbers of echinoderm remains (Boczarowski 2012, this issue). Although each group has been identified in the studied material, their proportions differ significantly in particular samples. This feature refers particularly to the taphonomy of those echinoderms whose skeletons are built from large number of tiny ossicles. Nev- ertheless, the common appearance of echinoderms, especially ophiuroids, indicates well oxidized bottom marine waters (Boczarowski 2012, this issue). The echinoderm assemblages from Gnaszyn are taxonomically rather impoverished (Boczarowski 2012, this issue); this feature may reflect relatively cold bottom waters. The dominance of holothurians, which are detritus-feeding motile benthic animals, suggests a high influx of plant remains from surrounding land areas. The majority of the echinoderm remains occur as isolated, scattered single particles, albeit in four samples articulated crinoid stems remain were found (Boczarowski 2012, Text-fig. 5, this issue). The presence of long pluricolumnals, up to $16 \mathrm{~cm}$ long, suggests that deposition took place during periods of calm conditions. Partly pyritized echinoderm elements and traces of anaerobic bacteria activity indicate oxygendepleted conditions in the sediment (Boczarowski 2012, this issue); the sediment/water interface represented the boundary between well oxygenated waters, inhabited by echinoderms, and dysaerobic sediment.

\section{Calcareous nannoplankton}

Calcareous nannoplankton was found in each of the forty samples (Kędzierski 2012, this issue). The nannoplankton assemblages display variable states of preservation; most commonly they are poorly to moderately preserved (partly dissolved and mechanically broken). The lowest diversity assemblages are noted in the lower part of the succession (Subcontractus and Morrisi ammonite zones); diversity gradually increases higher up in the succession (Bremeri Ammonite Zone), with sporadic reductions in diversity. The highest diversity occurs in the topmost part of the succession (Retrocostatum Ammonite Zone). The whole succession is dominated by the genus Watznaueria, which represents over $80 \%$ of the association.

Kędzierski (2012, this issue) relates frequency and diversity changes of calcareous nannoplankton assemblages to fluctuations in sedimentation rate and to changes in trophic conditions within the photic zone. The intervals with the most diverse assemblages also contain relatively high frequencies of palaeofertility indicators (Zeugrhabdotus erectus and Biscutum dubium), and are simultaneously impoverished in Watznaueria. This reflects a lower sedimentation rate and more stable, possibly mesotrophic conditions within the photic zone. In contrast, the low diversity, W. britannica-dominated assemblages, characterise periods of less stable conditions related to a higher influx of terrestrial material, resulting in a higher sedimentation rate and higher nutrient availability (eutrophic condi- 
PALAEOENVIRONMENT OF MIDDLE JURASSIC ORE-BEARING CLAYS

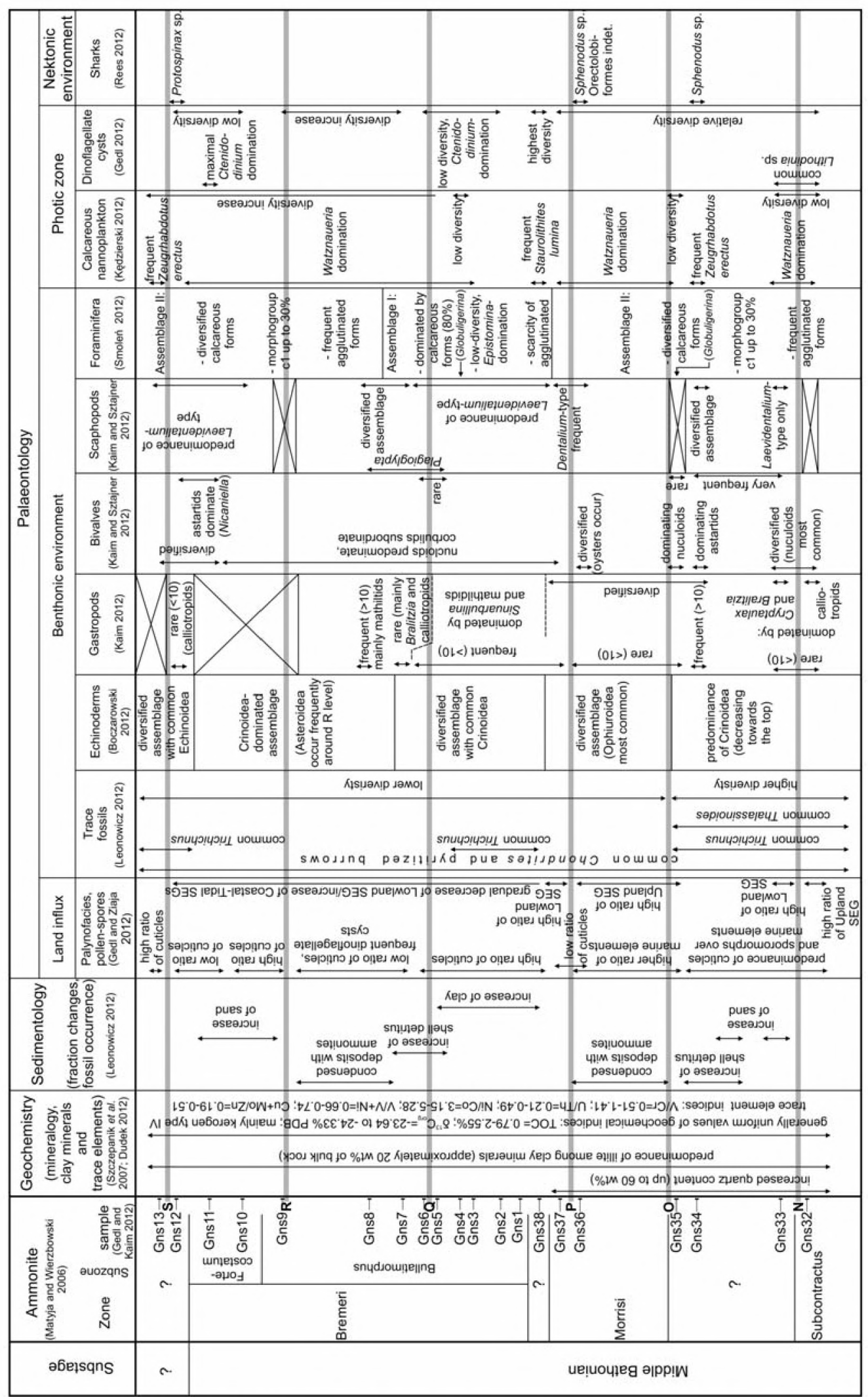

Text-fig. 4. Comparison of geochemical, sedimentological and palaeontological data of section A of the Gnaszyn succession. Abbreviations: SEG-sporomorphs eco-group; TOC - total organic carbon 
tion) in the photic zone. This, however, also reduces light availability due to the high amount of suspended

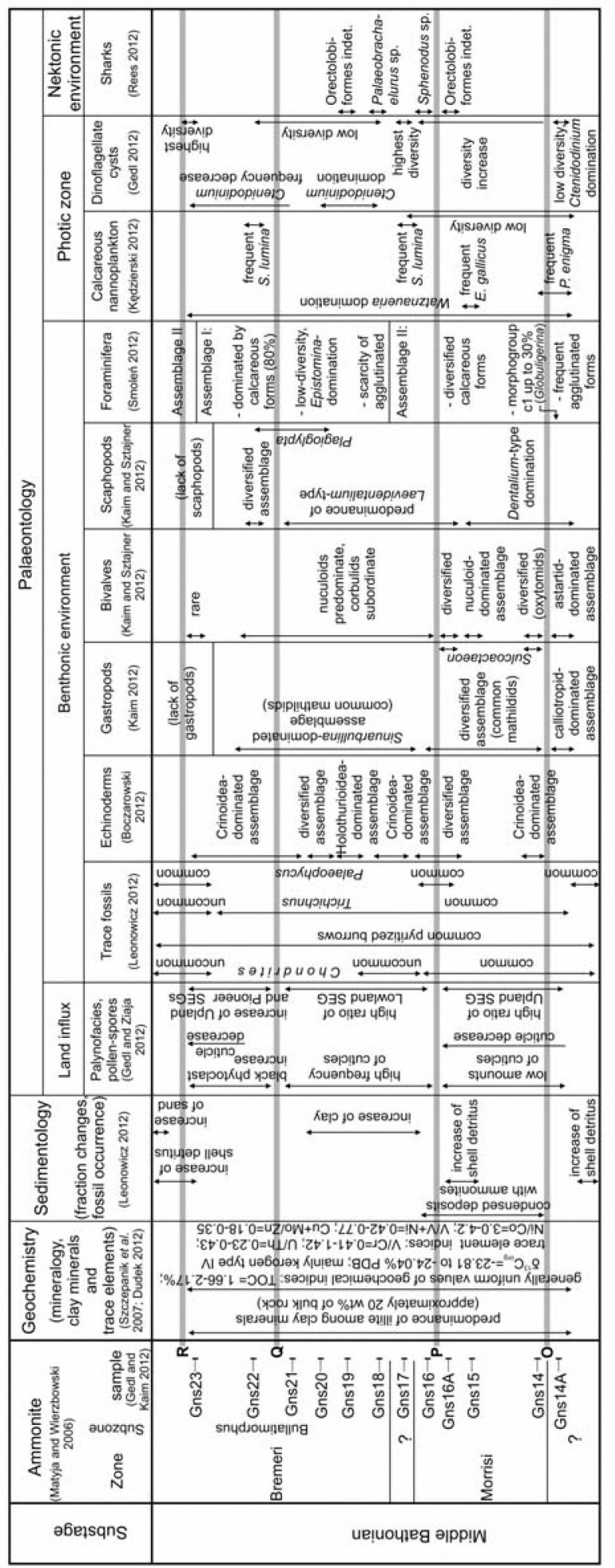

Text-fig. 5. Comparison of geochemical, sedimentological and palaeontological data of section B of the Gnaszyn succession. Abbreviations: SEG - sporomorphs eco-group; TOC - total organic carbon detrital material and organic matter, a situation tolerated by opportunistic species only.

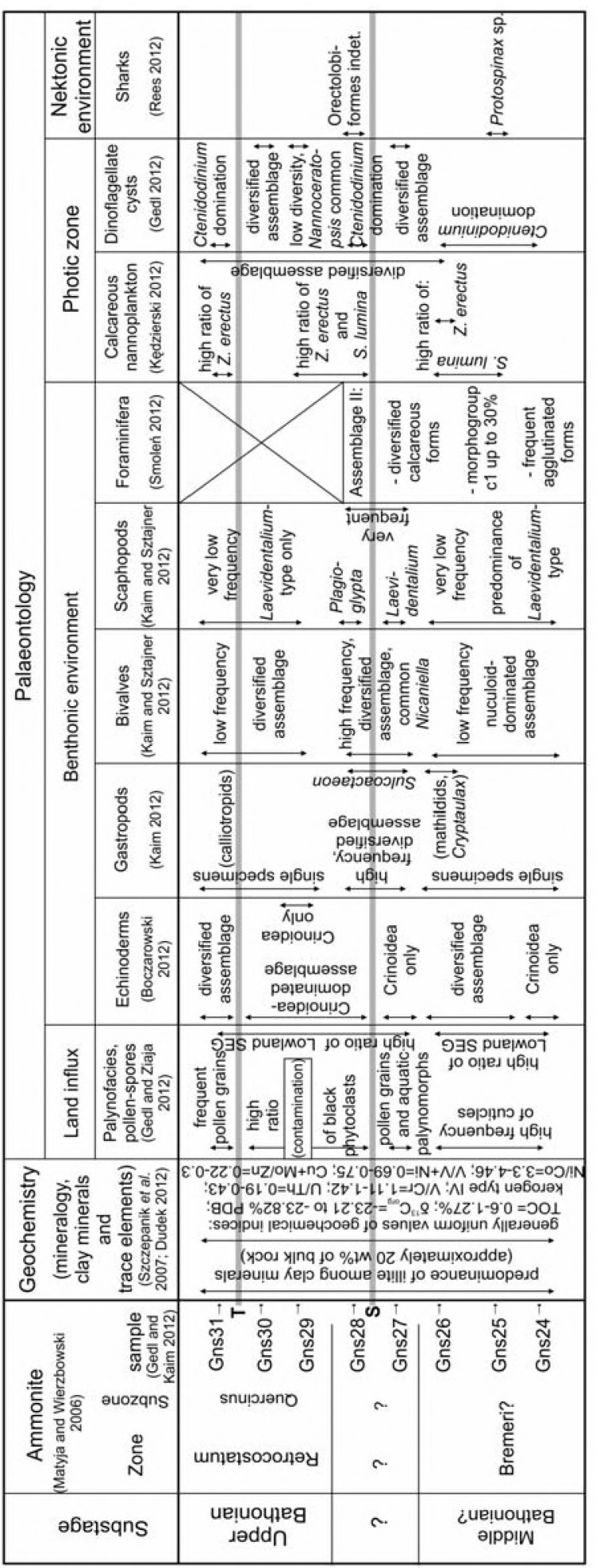

Text-fig. 6. Comparison of geochemical and palaeontological data of section C of the Gnaszyn succession. Abbreviations: SEG - sporomorphs eco-group; TOC - total organic carbon 


\section{Dinoflagellate cysts}

Dinoflagellate cysts occur in all of the samples, highly dispersed among the terrestrial phytoclasts and palynomorphs (Gedl 2012, this issue). Their assemblages are invariably dominated by a single species, Ctenidodinium combazii. Some assemblages, however, are taxonomically more diverse, with the dominance of $C$. combazii less pronounced. The highest diversity is noted in assemblages from the horizons with siderite concretions, whereas the lowest taxonomic diversity is shown by assemblages from the intervals between these horizons. These changes are interpreted as a response of the dinoflagellate cyst assemblages to changes in the Bathonian sea (Gedl 2012, this issue). Taxonomically impoverished assemblages presumably reflect slightly reduced salinity and/or an increase in eutrophication within the surface waters due to increased freshwater input. Such conditions were presumably favourable for the motile stage of Ctenidodinium. On the other hand, the more diverse assemblages reflect periods of less intense freshwater input and more normal salinity.

\section{Sharks}

Thirteen shark teeth from the Gnaszyn succession, representing five taxa (Sphenodus sp., Protospinax sp. 1, Protospinax sp. 2, Palaeobrachaelurus sp. and another, indeterminate, orectolobiform) are reported (Rees 2012, this issue). Almost all of the teeth were found in samples collected from horizons with siderite concretions.

The presence of the flattened and bottom-dwelling Protospinax and two different orectolobiforms that were likely to have lived near the bottom, clearly indicates well oxygenated bottom waters, particularly during the deposition of intervals now characterized by siderite concretions (Rees 2012, this issue)

\section{PALAEOENVIRONMENTAL RECONSTRUCTION}

Our studies show that the superficially monotonous Gnaszyn succession contains variable microfossil assemblages, which indicate rather variable palaeoenvironmental conditions at the time of its deposition. However, the amplitude of these changes was not high enough to be recorded in lithofacies type. Interpretation of the sensitivity of particular methods used in our multidisciplinary study may differ but, except for some geochemical parameters, they generally coincide in scale of magnitude. This shows that the microfossil assemblages were much more sensitive to even very slight environmental changes than the geochemical indices (see Szczepanik et al. 2007). Our reconstruction of the environmental processes at the time of deposition of the Gnaszyn succession is based on analysis of benthic and planktonic fossils (mainly microfossils), as well as those of terrestrial origin, transported by rivers or wind into the marine basin.

\section{The bottom environment}

Among the benthic groups studied are echinoderms, gastropods, bivalves, scaphopods and foraminifera. Additional benthic animals are recorded by traces of their activity. Sharks, although nectonic, were also at least near-bottom dwellers in the basin (Rees 2012, this issue). All benthic groups from the Gnaszyn succession, including oxygen-sensitive echinoderms and scaphopods, indicate relatively welloxygenated bottom waters.

Anoxic bottom conditions, despite the dark colour of sediment, can be excluded. Similar conclusions are based on geochemical analysis (Szczepanik et al. 2007). However, the latter indicates stable oxic conditions in the bottom environments, whereas the benthic fossil groups indicate fluctuating conditions, possibly related to variable oxygen content.

The Subcontractus to Morrisi ammonite zones contain relatively diverse foraminifera which favoured well-oxygenated bottom environments with sufficient food supply (Smolen 2012, this issue). Juvenile molluscs have a more variable distribution pattern in this interval; quite diverse in some samples but impoverished or missing in others (Text-figs 4,5). This variation in diversity may be related to palaeoenvironmental conditions in the bottom water: the dominance of adult or adolescent gastropods indicates appropriate living conditions allowing their full growth (Kaim 2012, this issue; Kaim and Sztajner 2012, this issue). The occurrence of frequent juvenile forms, on the other hand, may indicate some deterioration of living conditions, possibly related to oxygen depletion or a faster sedimentation rate. Within the Subcontractus-Morrisi zones the molluscs are impoverished numerically and rather poorly preserved in samples from the intervals with concretion horizons (Kaim 2012, this issue). Also scaphopods and bivalves show the lowest abundances in samples taken from intervals just below concretion horizons (Kaim and Sztajner 2012, this issue). Such patterns in benthic molluse distribution may be a result of a relatively low sedimentation rate.

Well-oxygenated bottom waters, and a relatively low sedimentation rate during the Subcontractus-Mor- 
risi zones could also be concluded from the occurrence of neoselachian sharks; these are most frequent in the intervals with concretion horizons (Rees 2012, this issue). Because at least some of these sharks were living in bottom waters, their presence indicates aerobic conditions. We are unable, however, to exclude the possibility that some enrichment in shark teeth in these strata could have resulted from time-averaging.

The lower Bremeri Zone yielded rich, albeit compositionally different and more uniform, benthic microfossil assemblages (Text-figs 4, 5). The foraminiferal assemblages are much less diverse and consist mainly of small-sized Epistomina and of rare agglutinated forms. This change in the foraminiferal assemblages results from a higher deposition rate, which, due to a higher influx of organic particles, led to slight oxygen depletion in both sediment and bottom waters (Smoleń 2012, this issue). Similar conclusions are suggested by more numerous but taxonomically impoverished gastropod assemblages (Kaim 2012, text-fig. 3, this issue), and scaphopods and bivalves (Kaim and Sztajner 2012, text-figs 3, 4, this issue, respectively). The gastropods, much more frequent than in the underlying zones, are dominated by the cylindrobullinid Sinuarbullina and mathildids, which preyed on sedentary organisms and could also flourish during periods of higher sedimentation rate and oxygen-deficient near bottom conditions if these organisms were still present (Kaim 2012, this issue) while cerithiids, rissoids, aporrhaids and eucyclids are used to live on microbial films and epigrowths, which require slower sedimentation and stable oxygenation. Nuculoid-dominated bivalves and Laevidentalium-type scaphopods favour soft-bottom conditions (Kaim and Sztajner 2012, this issue) while more diverse bivalve and scaphopod biota dominated by sluggish astartids and byssate pterioids from intervals with concretion horizons occur in periods of slower sedimentation and/or firmer bottom condition.

The upper Bremeri Zone yields more diverse benthic assemblages, similar to those from the Subcontractus-Morrisi zones. This change starts with concretion horizon Q, but is more pronounced above it. Plagioglypta occurs below horizon $\mathrm{Q}$ and a higher diversity scaphopod assemblage occurs above it (Text-figs 4, 5).

The gastropods also show some quantitative and qualitative changes in the upper Bremeri Zone. Noteworthy is the occurrence of articulated long crinoid pluricolumnal above concretion horizons $\mathrm{Q}, \mathrm{R}$, and S (Boczarowski 2012, this issue), which indicate calm depositional conditions.

Starting with sample Gns8 (section A) and above sample Gns22 (section B), Smolen (2012, this issue) noted a change in the composition of the foraminiferal assemblages, which in their higher diversity and frequent occurrence of agglutinated forms resemble assemblages from the Subcontractus-Morrisi zones. Such changes are not observed in the bivalve assemblages, which remain virtually unchanged (see Kaim and Sztajner 2012, text-fig. 3, this issue).

These changes in benthic associations are most likely related to a decrease in sedimentation rate and a return of palaeoenvironmental conditions similar to those that prevailed during the period of the Subcontractus-Morrisi zones. Benthos that favours a higher and/or more stable oxygen content, slower sedimentation rate and a firmer substratum flourished during the deposition of the upper part of the Gnaszyn succession.

The uppermost part of the Gnaszyn succession, i.e., the strata above the Fortecostatum Subzone and the Retrocostatum Zone (Text-figs 4, 6) yielded much more diverse benthic fossils typical of more favourable living conditions than the ones below.

The nuculoid-dominated bivalve assemblages of the Bremeri Zone are replaced by a diverse assemblage with common Nicaniella (Trautscholdia) and other astartids (Text-fig. 6). Astartids are also frequent in the lower part of the succession in sample Gns34 (Kaim and Sztajner 2012, text-fig. 6, this issue). Also the gastropod assemblages (including common $\mathrm{Bral}^{-}$ itzia and mathildids which occur in samples Gns27 and Gns28) resemble those from the intervals with siderite concretions of the Morrisi Zone (Text-fig. 5). Both intervals are also characterized by the frequent occurrence of Sulcoactaeon, and by similar foraminiferal assemblages. The scaphopods from the topmost part of section C (uppermost Bremeri? and Retrocostatum zones) are taxonomically diverse, consisting of Dentalium- (sample Gns27), Plagioglypta(sample Gns28) and Laevidentalium-type scaphopods (Kaim and Sztajner 2012, this issue).

There is no clear correlation between benthic assemblages and grain size, which varies significantly within the Subcontractus-Morrisi zones (see Leonowicz 2012, this issue and Dudek 2012, this issue). However, we observed that the samples from coarsergrained strata usually yielded more numerous and more diverse molluscs than the samples from the silty clays; which might be related to an oxygen-depleted environment and/or a faster sedimentation rate.

\section{The photic zone}

The microfossils from the Gnaszyn succession that inhabited the photic zone include calcareous nannoplankton and dinoflagellate cysts; the uncommon planktonic foraminifer Gubkinella (Globuligerina) 
bathoniana, is not directly associated with the photic zone). As in the case of the benthic microfossils, the planktonic groups also show quantitative and qualitative variation in the succession, reflecting some subtle environmental changes that affected the surface water layer at the time of deposition.

Both the calcareous nannoplankton and the dinoflagellate cysts are characterized by low diversity and the dominance of a single taxon. The former are composed chiefly of the genus Watznaueria (mainly W. britannica; Kędzierski 2012, this issue) whereas the latter are dominated by the genus Ctenidodinium (mainly C. combazii; Gedl 2012, this issue). The frequencies of both dominant genera oscillate between $50-80 \%$ (Watznaueria) and from $35 \%$ to over $85 \%$ (Ctenidodinium).

The planktonic foraminifer Gubkinella (Globuligerina) bathoniana occurs exclusively in three samples (Gns4, Gns35, Gns14A; Smoleń 2012, this issue). The appearance of this planktonic species at the base of the Morrisi Zone apparently reflects specific environmental conditions for planktonic species that are virtually absent elsewhere in the succession. Its occurrence is presumably related to northward-migrating low-latitude waters, since this species is a typical Tethyan taxon.

Generally, the Subcontractus-Morrisi zones contain rather low-diversity calcareous nannoplankton assemblages, whereas the taxonomic diversity of the dinoflagellate cysts is relatively high. Especially the samples from above the interval with concretion horizons contain assemblages with the genus Ctenidodinium, which, although dominating, shows relatively low values - from 25 up to $60 \%$. The two lowermost samples (Gns32 and Gns33) yielded an exceptional dinoflagellate cyst assemblage containing an unusual high proportion of the genus Lithodinia. Such a composition could be interpreted as indicative of more stable conditions in the photic zone during the Subcontractus-Morrisi zones than during the deposition of the following Bremeri Zone, which contain low-diversity, Ctenidodinium-dominated dinoflagellate cyst assemblages (Ged1 2012, this issue). Calcareous nannoplankton assemblages from this interval, albeit dominated by Watznaueria, show a few peaks of particular species frequency. Sample Gns34 yielded relatively numerous specimens of Zeugrhabdotus erectus and Pseudoconus enigma; the latter species occurs commonly in samples Gns14 and Gns14A. Samples Gns35 and Gns36 and Gns15 contain high numbers of Ethmorhabdus gallicus. According to Kędzierski (2012, this issue), the occurrence of these species in the basal part of the Gnaszyn succes- sion reflects relatively stable marine conditions in the photic zone, and presumably a lower sedimentation rate compared to the overlying strata. This interpretation agrees well with the one based on dinoflagellate cyst assemblages and planktonic foraminifers. The benthic biota from this interval also indicates a lower sedimentation rate at that time.

The Bremeri Zone contains calcareous nannoplankton and dinoflagellate cyst assemblages composed of dominant species: Watznaueria britannica and Ctenidodinium combazii respectively. W. britannica-dominated assemblages have been interpreted as a result of more unstable conditions reflecting a higher influx of terrestrial material leading to eutrophic condition in the photic zone, and consequently to light reduction due to higher amounts of suspended detrital material and organic matter (Kędzierski 2012, this issue). Such conditions seemingly favoured the motile stages of Ctenidodinium combazii, which dominated the dinoflagellate cyst assemblages at that time (Gedl 2012, this issue).

The planktonic assemblages show, however, some subtle fluctuations within the Bremeri Zone, possibly related to changes in surface water fertility. Kędzierski (2012, this issue) distinguished within this interval of relatively high mesotrophy (compared to the low-mesotrophic underlying strata of the Subcontractus-Morrisi zones) several intervals of relatively lower nutrient availability. Dinoflagellate cyst assemblages from the Bremeri Zone also underwent some changes. Domination of the genus Ctenidodinium is most pronounced in the lower part of the zone, below the Q concretion level and in its uppermost part (Fortecostatum Subzone). Correlation of these results with Kędzierski's (2012, this issue) interpretation shows that the most diverse dinoflagellate cyst assemblages often come from samples that yielded coccolith assemblages typical of moderate or high mesotrophy. The samples with the highest frequency of Ctenidodinium are interpreted by Kędzierski (2012, this issue) as low mesotrophic.

Planktonic assemblages from the topmost part of the Gnaszyn succession exposed in section C show high variability. The lowermost, muddy part contains calcareous nannoplankton which, according to Kędzierski (2012, this issue), is indicative of rather fertile surface waters. Similar conditions concerning mesotrophy were deduced by Kędzierski (2012, this issue) from the coeval topmost interval of section A, whereas the overlying sample Gns 13 yielded a high mesotrophic assemblage. Dinoflagellate cysts from these samples are dominated (up to $60 \%$ ) by Ctenidodinium (Gedl 2012, this issue). 
The higher sample Gns27 collected below the S concretion level, already displays less common indicators of high fertility, whereas the dinoflagellate cyst assemblages are more diverse (Ctenidodinium represents up to $25 \%$ of the assemblage). Pareodinia sp. occurs in this sample in exceptionally high numbers, reaching almost $20 \%$ of the assemblage.

A rapid change in calcareous nannoplankton assemblages was noted in sample Gns28 collected above the $\mathrm{S}$ concretion level, and in the higher samples Gns29-31. High numbers of S. lumina and Z. erectus in these samples are, according to Kędzierski (2012, this issue), an indication of high mesotrophic conditions.

Dinoflagellate cysts from this interval show high variability (Gedl 2012, this issue). Sample Gns28 contains a relatively diverse assemblage, albeit not of such high diversity as in the underlying sample Gns27. Ctenidodinium specimens are not as numerous as below, suggesting more stable conditions at the time of deposition of the topmost part of section C section. However, sample Gns29 yielded very common $\mathrm{Nan}$ noceratopsis pellucida, whose occurrence in such a high percentage (40\%) may reflect some other unstable conditions in the photic zone. The diversity of the dinoflagellate cyst assemblage drops again in the topmost sample Gns 31 , which contains almost $60 \%$ of Ctenidodinium, an assemblage reminiscent of those from samples (Gns24-26) collected from the lower part of section $\mathrm{C}$.

\section{SYNTHETIC INTERPRETATION}

Interpretation of our data shows that the deposition of the Gnaszyn succession reflects a complex relationship of land and marine ecosystems with sea-level fluctuations involving variable intensity of terrestrial material input, which, in turn, influenced the environment in the photic zone, controlling the productivity of phytoplankton. The interacting biomass volume of the latter and the land-derived organic particles was crucial for the benthic ecosystem. Our model of the deposition of the Gnaszyn succession includes phases characteristic of low and high sea-level periods (Text-figs 7 and 8 , respectively).

\section{High sea-level phases}

During relatively high sea-level periods, marine waters flooded the neighbouring land areas and the source area for the terrestrial palynodebris (i.e., the emerged area with vegetation) became more remote from the marine depositional setting (Text-fig. 7). This resulted in a palynofacies composition that contains high proportions of black opaque phytoclasts - an element typical of a marine offshore setting with a limited influx of land-derived material. Cuticle remains, which occur in higher concentrations in more proximal settings, are less numerous. The sporomorph assemblages contain high proportions of taxa characteristic of communities growing in the hinterland (Upland SEG) and of those colonizing land in front of the encroaching sea (Pioneer SEG). The dinoflagellate cysts show relatively high proportions compared to the terrestrial palynodebris. Moreover, the dinoflagellate cyst and calcareous nannoplankton assemblages are taxonomically more diverse. This reflects marine conditions in the photic zone, which are affected to a lesser extent by freshwater influx from the more remote river mouths. A relatively lower influx of terrestrial organic matter (and of clastic particles causing a lower sedimentation rate), resulting from a more remote source area, led to better living conditions in the bottom water zone This benefited the benthic animals (e.g. foraminifera and molluses) due to a lower sedimentation rate. The foraminifera are taxonomically well diversified and the molluses, though infrequent, reached adolescent/adult stages. Relatively calm sedimentation during these periods enabled the preservation of articulated stems of crinoids, which occur only in the vicinities of the concretion levels. Another animal group that was able to benefit from these bottom conditions were the neoselachian sharks, which penetrated the uppermost bottom layer in the search for food. The conditions of higher sea level present in the topmost part of the sediment generated equilibrium between decomposed organic matter, oxygen and carbon dioxide content and reduced ferrous ion availability, favouring the early diagenetic precipitation of siderite concretions.

\section{Low sea-level phases}

Different conditions appeared during periods of sea-level fall. Regression of the sea exposed vast lowland areas available for the vegetation that produced sporomorphs of the Lowland SEG, which are commonly found those intervals representing sea-level lowstand (Text-fig. 8). Together with the sporomorphs, high amounts of palynodebris, including cuticles, were transported into the marine basin by intense influx of material from relatively closely situated river mouths. This could have led at least periodically to a decrease in salinity in the topmost part of the photic zone. Additionally, the rivers would have 
PALAEOENVIRONMENT OF MIDDLE JURASSIC ORE-BEARING CLAYS

supplied high amounts of nutrients, causing eutrophication of the surface waters. Such conditions within the photic zone resulted in blooms of specific taxa, which dominated planktonic assemblages of dinofla- gellates (Ctenidodinium) and calcareous nannoplankton (Watznaueria). Increased influx of organic matter, associated with faster sedimentation, caused unfavourable bottom living conditions. Bacterial decay

\section{High sea-level phase}
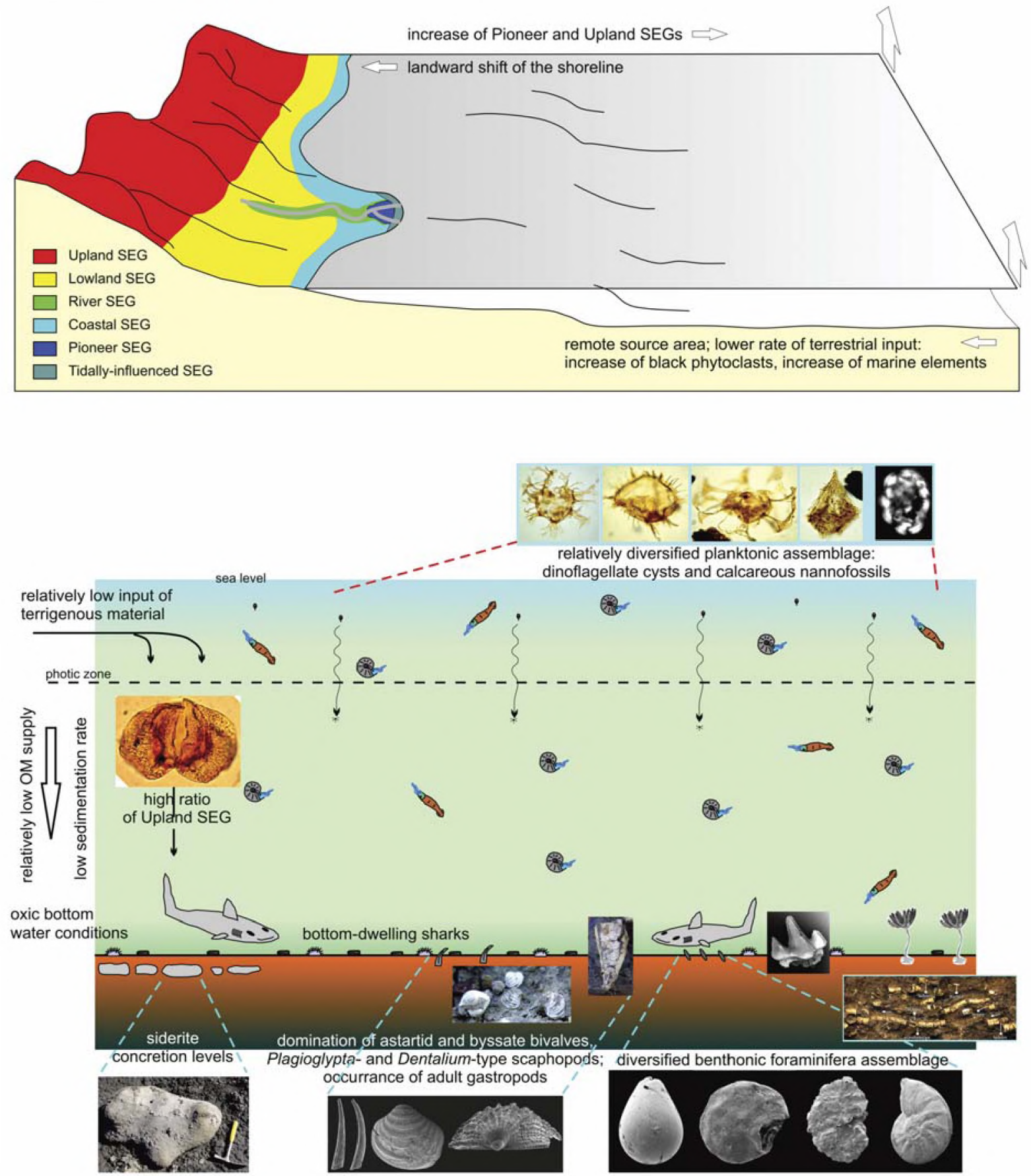

Text-fig. 7. Conceptual model of palaeoenvironmental conditions of high-sea phase during the ore-bearing clay deposition at Gnaszyn (Middle Bathonian-earliest Late Bathonian). Abbreviations: SEG - sporomorphs eco-group; OM - organic matter 
of high amounts of organic matter depleted the oxygen supply and the sea bottom became hostile for benthic animals. Even in periods of relatively good oxygenation the high sedimentation rate impeded the colo- nization of the soft substratum by benthic organisms. All these factors also caused taxonomic impoverishment of the foraminiferal assemblages which were dominated by small-sized individuals of the oppor-
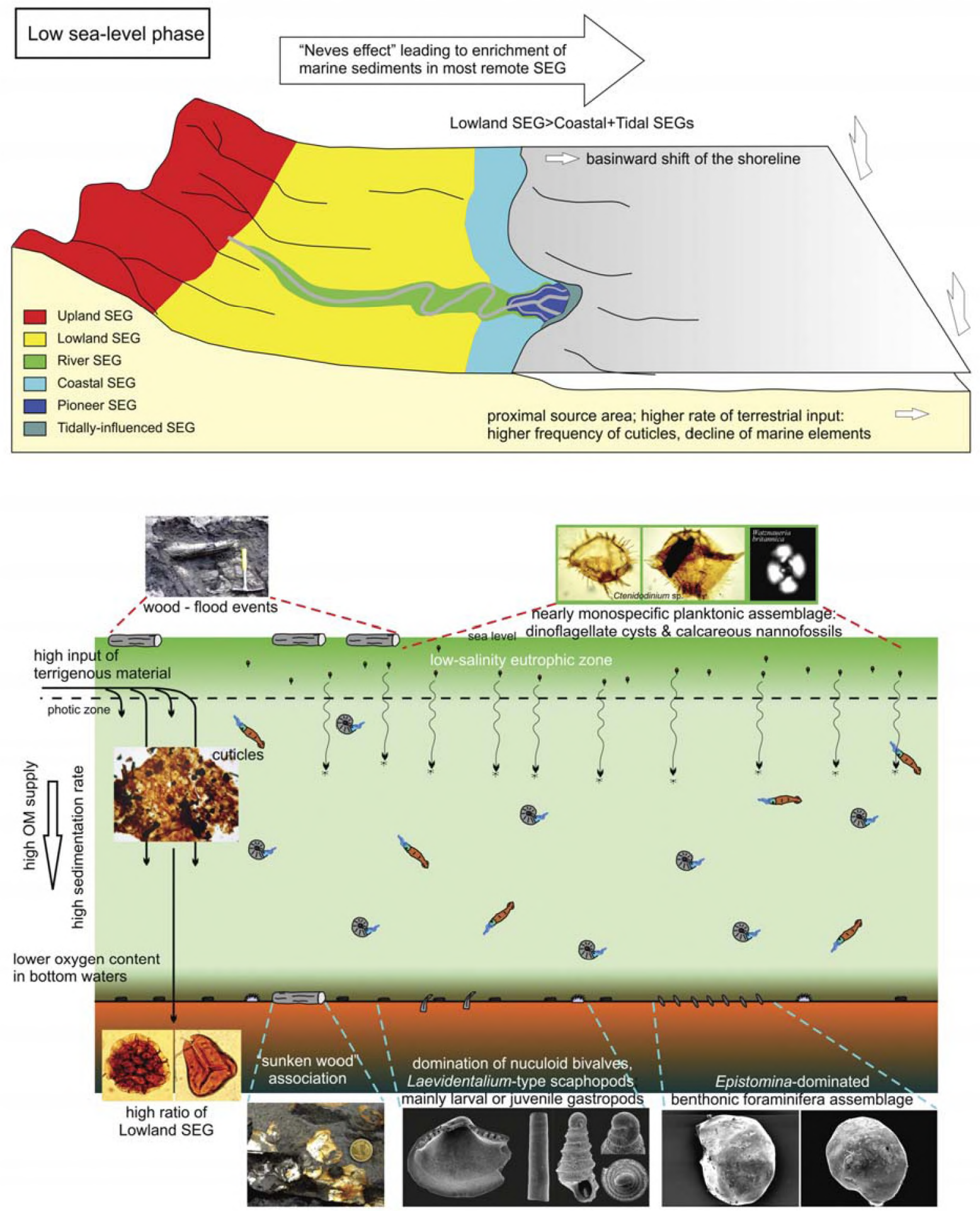

Text-fig. 8. Conceptual model of palaeoenvironmental conditions of low-sea phase during the ore-bearing clay deposition at Gnaszyn (Middle Bathonian-earliest Late Bathonian). Abbreviations: SEG - sporomorphs eco-group; OM - organic matter 
tunistic species Epistomina nuda. The molluscs, on the other hand, are dominated by juvenile forms. Their presence also indicates unstable conditions, which presumably due to variation in oxygen content, prevented their development into adult stages. The oxygen depletion was also unfavourable for the growth of siderite concretions during early diagenesis.

\section{DISCUSSION}

The range of environmental parameters controlling the deposition of the ore-bearing clays is assessed here based on palaeontological and sedimentological studies carried out within the framework of our project. We emphasize that our study was aimed at a detailed investigation of a single outcrop, with the assumption that the results can safely be applied to the interpretation of the whole area of the Kraków-Częstochowa basin. Such an approach may be the reason for some inconsistencies in our interpretation when compared with interpretations based on a more generalized approach, as used by other authors.

Terrestrial influx and bottom water aerobic conditions. Palynofacies and palaeontological analyses demonstrate the ubiquity of terrestrial elements throughout the Gnaszyn succession (Gedl et al. 2003, 2006c; Gedl and Ziaja 2012, this issue). This had been expected in view of the common occurrence of macroscopic vascular plant remains (Gedl et al. 2003, 2006c; Zatoń et al. 2006; Marynowski et al. 2007a; Philippe et al. 2006; Kaim 2011; Gedl and Kaim 2012, this issue) and geochemical studies documenting high amounts of organic matter (TOC from 1.5 to $2.5 \mathrm{wt}$ \% \%) of mainly terrestrial origin (kerogen type III and/or IV; Szczepanik et al. 2007; Marynowski et al. 2007b). Despite the high influx of organic matter, the whole Gnaszyn succession was deposited in relatively welloxygenated (oxic to suboxic) bottom waters, as indicated both by geochemical characteristics (Szczepanik et al. 2007; Marynowski et al. 2007b; see also Zatoń et al. 2009) and our palaeontological data (Smoleń 2012, this issue; Kaim 2012, this issue; Kaim and Sztajner 2012, this issue).

Palaeogeography. The presence of river mouths agrees with general palaeogeographic reconstructions of southern Poland during the Bajocian-Bathonian, which suggests a landmass south and south-west of the Częstochowa area (the Silesia and Małopolska lands; Text-fig. 1). The ore-bearing clays wedge out gradually southwards and, near Kraków, are replaced by the continental Grojec clays, which are rich in vascular plant remains, including ubiquitous sporomorphs. Marynowski et al. (2007b) proposed that Fennosarmatia (see Text-fig. 2) was the main source area for the Bathonian sea in Poland. However, the same authors Marynowski et al. 2007b, p. 2479) also presented another interpretation, suggesting the Bohemian Massif as a main source of pteridosperm detritus. The latter alimentary area for the Gnaszyn succession is suggested by the presence of large cuticle fragments, which indicate short transport (Gedl and Ziaja 2012, this issue).

Water depth. Smoleń (2012, this issue) noted foraminiferal assemblages typical of inner to outer shelf and even upper continental slope settings (i.e., depths from tens up to a few hundred metres). The presence of glauconite, if authigenic, led Dudek (2012, this issue) to conclude that basin depth was within the range of 60 to $1000 \mathrm{~m}$. Leonowicz (2012, this issue) located the depositional setting of Gnaszyn in the offshore zone, below the wave base, but close enough to the shore to record sporadic storm-generated offshore flows (see also Merta and Drewniak 1998 fide in Zatoń and Marynowski 2004). Overturned and abraded concretions found by Zatoń et al. (2011) may indicate occasional storms reaching the bottom. Some of the gastropods identified by Kaim (2012, this issue) are typical of the deep-water outer shelf, occurring nowadays at depths of few hundred metres. Important for depth interpretation would be proof that the bottom was within reach of the photic zone or deeper. We found no direct evidence that sunlight reached the bottom of the Gnaszyn sea: the presence of bryozoans and oysters, with a simultaneous lack of corals on the wood-fall association described by Kaim (2011), may support the interpretation that the bottom of the sea at Gnaszyn was below the photic zone. We found no benthic forms (e.g., gastropods) preying on photosynthesizing elements. Certainly, the depth to which the photic zone extends depends not only on the depth of the water but also on its transparency, and the latter could have been greatly reduced in the basin due to the dense suspension of clastic and organic particles.

Climate. Gedl and Ziaja (2012, this issue), based on sporomorphs (high frequency of Araucariaceae and ferns), suggested a warm climate without seasonal amplitudes on the surrounding land. A contradictory interpretation, with cold and dry climatic conditions, was suggested by Dudek (2012, this issue), based on the illite/kaolinite ratios in the succession. The palaeoclimate of the Middle Jurassic in Europe is believed to 

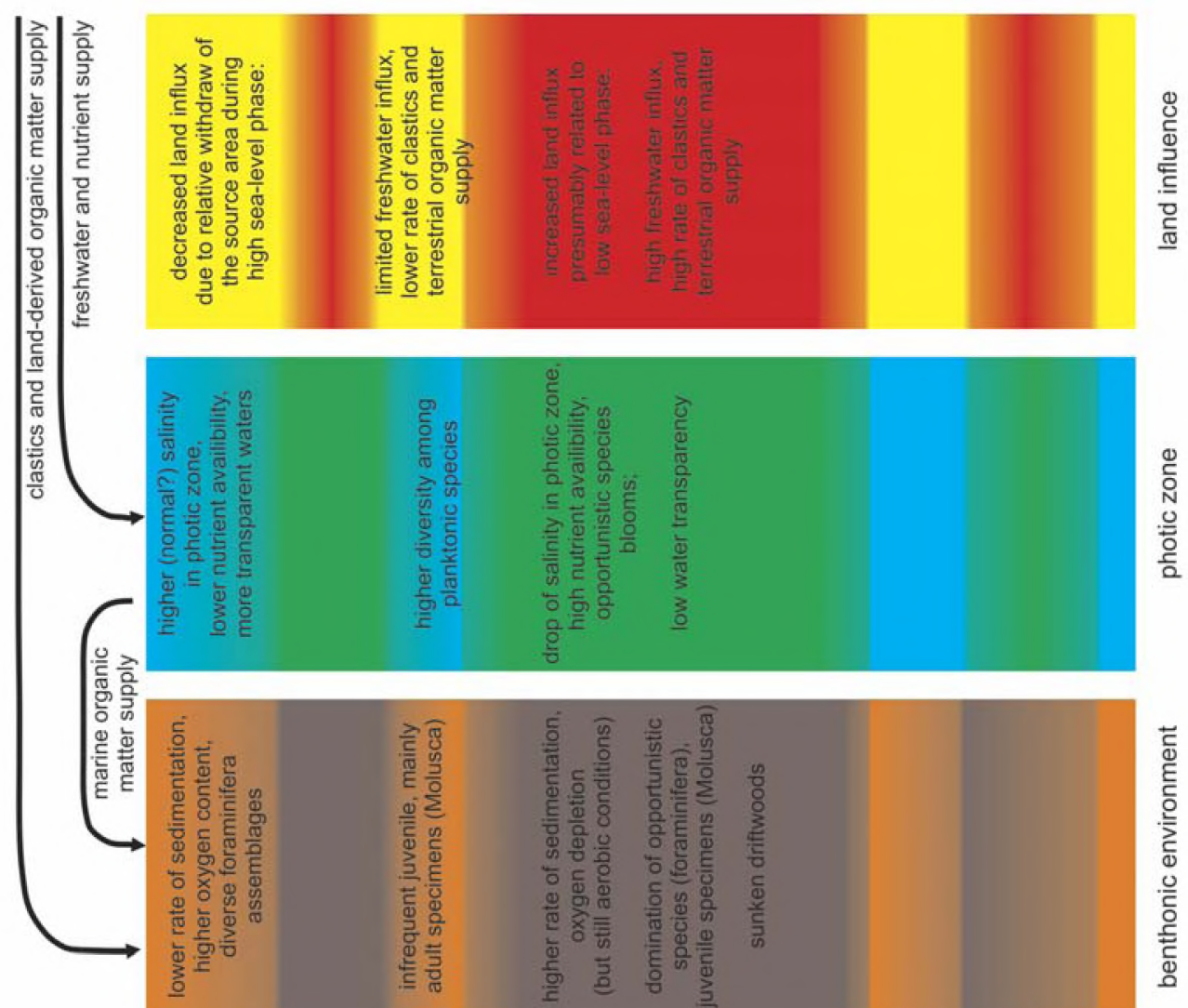
$\Theta$ (ळ)
(ㅅ)
(C)
() ()
(2)

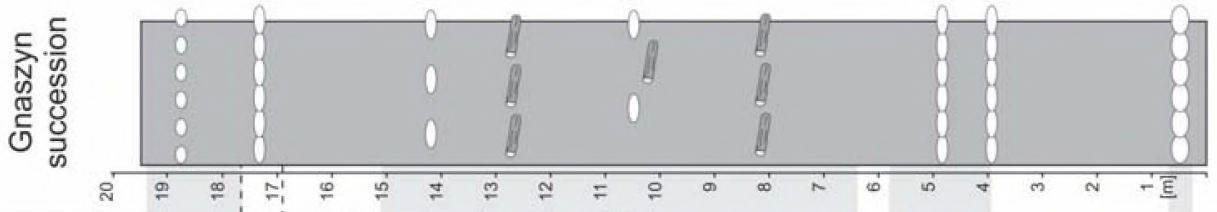

\begin{tabular}{|c|c|c|c|c|c|c|}
\hline \multirow{2}{*}{ 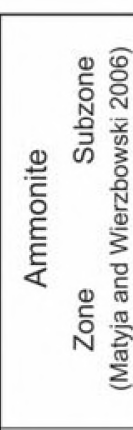 } & 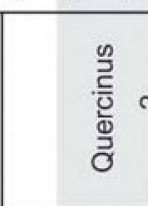 & 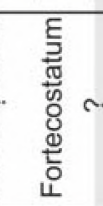 & 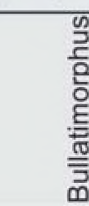 & & & \\
\hline & 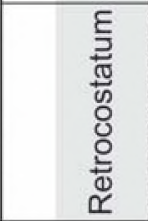 & & $\begin{array}{l}\overline{\bar{\Phi}} \\
\bar{E} \\
\bar{\Phi} \\
\bar{\omega}\end{array}$ & 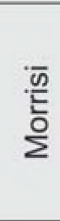 & $\sim$ & 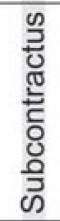 \\
\hline ә6етsc & $\begin{array}{l}\text { uepuouypeg } \\
\text { dəddn }\end{array}$ & & & !! & & \\
\hline
\end{tabular}

Text-fig. 9. Summary of palaeoenvironmental changes during Middle Bathonian (Subcontractus Ammonite Zone)-early Late Bathonian (Retrocostatum Ammonite Zone) at Gnaszyn. Low sea-level conditions (yellow colour on right-hand column) involve increased supply of organic matter and clastic material into the basin, which resulted in a drop of salinity and eutrophication of the waters of the photic zone (green colour in the middle column), and, as a consequence, led to faster sedimentation rate and oxygen depletion in the bottom environment (unfavourable living conditions: brown colour in the left-hand column). Higher sea-level, on the other hand, caused limited terrestrial input into the basin (red colour), which resulted in a lower salinity drop in the photic zone (yellow colour in the middle column), and optimal living conditions at the bottom (higher oxygen content and sufficient food supply; orange colour in the left-hand column) leading to development of diversified benthic biota 
have been warm and humid (e.g., Hallam 1984, 1985; Frakes et al. 1992), fitting our interpretation based on the vegetation record.

Sea water temperature. The temperatures of sea water in the Middle Bathonian of Poland were investigated by Malchus and Steuber (2002) and Wierzbowski and Joachimski (2007) based on the carbon and oxygen isotopic ratios from marine calcareous fossils. Malchus and Steuber (2002) studied fossils from NW Poland (Kłęby) while Wierzbowski and Joachimski studied fossils from the ore-bearing clays in the Częstochowa and Wieluń regions. Malchus and Steuber (2002) inferred $\sim 18-27^{\circ} \mathrm{C}$ for the bottom (benthos) and $\sim 17^{\circ} \mathrm{C}$ for the surface waters (ammonoids); whereas Wierzbowski and Joachimski (2007) inferred $\sim 4-9.5^{\circ} \mathrm{C}$ for the bottom (trigoniids) and $\sim 16-22^{\circ} \mathrm{C}$ for surface waters (ammonoids). However, we should emphasize that the record of surface water temperature provided by Malchus and Steuber (2002) was obtained from a single ammonoid shell which provided values lower than the coeval benthic bivalves, and this casts some doubts on this record. The discrepancy in benthic water temperatures between those provided by Malchus and Steuber (2002) and by Wierzbowski and Joachimski (2007) may have resulted, at last partially, from the much shallower, coastal setting of the Middle Bathonian sediments in NW Poland (at Kłęby) compared to the more offshore setting of the ore-bearing clays, and, as argued by Wierzbowski and Joachimski (2007) from a slightly different equation used for the calculation of temperatures from isotope ratios. This problem requires further investigations (Wierzbowski and Joachimski 2007).

The sea water temperature might also have been related to the sea current circulation pattern. The generally accepted direction of sea-water circulation during the Bathonian in Poland assumes northward movement of Tethyan waters (Dayczak-Calikowska 1997), which would bring warm-water masses into the Polish basin. This view is supported by ammonite data (e.g., Matyja and Wierzbowski 2000; Zatoń and Marynowski 2004, 2006). Moreover, Smoleń (2012, this issue) noted the presence of the Tethyan planktonic foraminifer Gubkinella (Globuligerina) bathoniana, albeit only at single levels. On the other hand, the presence of the fossil wood Xenoxylon in Gnaszyn (Philippe et al. 2006; Marynowski et al. 2008) may reflect a colder and humid climate in the area where the trees grew (Philippe and Thévenard 1996). The occurrence of this wood at some levels only, like the occurrence of Gubkinella (Globuligerina) bathoniana at other levels, might indicate that Gnaszyn area was influenced by warmer and colder sea currents of variable intensity over time.

Wierzbowski and Joachimski (2007) argue that the unrealistically large temperature gradient observed between the benthic and nektonic organisms might be at least partially explained by the lowered salinity of the surface waters. A decrease in salinity to $29 \%$ would result in a decrease of average palaeotemperatures calculated from ammonites to $14.9^{\circ} \mathrm{C}$ (originally 18.6 ${ }^{\circ} \mathrm{C}$ ). Such a decrease in salinity is supported in our data by blooms of opportunistic phytoplankton. Nevertheless, some temperature stratification during the deposition of ore-bearing clays cannot be excluded (Marynowski et al. 2007b).

\section{SUMMARY}

1. The Middle-lower Upper Bathonian (Subcontractus-Retrocostatum ammonite zones) succession exposed at Gnaszyn has been studied for geochemistry, sedimentology (including ichnology), sporomorphs, palynofacies, micropalaeontology of benthonic (foraminifera, gastropods, bivalves, scaphopods, echinoderms), planktonic (calcareous nannoplankton, dinoflagellate cysts), and nektonic (sharks) fossils. Each study, except for sedimentology, was performed on the same set of forty samples collected from three, partially overlapping sections.

2. The study presented herein has shown that an analysis of several fossil groups from the same set of samples, supported by sedimentological and geochemical data is a powerful tool for palaeoenvironmental reconstructions. The combination of all these study methods enables reconstruction of the interaction between processes that took place in proximal marine environment and terrestrial influences, including sea water chemistry, planktonic, nectonic and benthic biotas. However, since the various fossil groups may have different sensitivities, and our knowledge of the palaeoenvironmental preferences of particular groups is at different levels of understanding, the final interpretation presented here has to be treated circumspectly and it is not surprising that some of the interpretations are contradictory.

3. The sedimentary setting of the Gnaszyn succession was located relatively close to the shoreline, within reach of an intense supply of terrestrial fine-clastic and organic particles. Most likely its source area 
was located to the south-west, on the Bohemian Massif. The presence of glauconite and benthic foraminifera typical of shelf to upper continental slope settings suggests depth ranging from several tens to a few hundred metres. Sedimentological analysis suggests an offshore zone below the fair weather wave base, but within reach of storm-generated offshore flows. There is no evidence of sunlight reaching the bottom of the sea, which would indicate water depths greater than $200 \mathrm{~m}$. However, the dense suspension of fine terrestrial grains and organic particles, which predominated during deposition of the Gnaszyn succession, may have limited the depth of the photic zone to less than $200 \mathrm{~m}$.

4. The abundance of Araucariaceae and ferns suggest a warm climate without seasonal amplitudes. On the other hand, a contradictory interpretation of the climatic conditions might be drawn from clay mineral analysis. The apparent dominance of illite over kaolinite in the Gnaszyn succession indicates intensive mechanical weathering of the rocks in the source area, which is typical of temperate, cold and dry climatic conditions. The former option supports the Bohemian Massif as an alimentary area, whereas the latter one indicates the more remote, higher-latitude Fennosarmatia land as the source area for the Gnaszyn succession sediments.

5. The analysis of palynofacies shows a variable intensity of terrestrial organic matter input (Text-fig. 9). Correlation with sporomorph distribution indicates an intermittent shoreline position presumably related to sea-level changes and periodic flooding of the coastal lowlands. These changes caused variable amounts of terrigenous material input into the marine basin. During relatively lower sea-level phases an increased terrestrial influx is evidenced. Intensified river activity caused a decrease in salinity and the significant amounts of organic and inorganic particles limited the water transparency in the photic zone. As a consequence, stress conditions in the photic zone caused blooms of opportunistic planktonic taxa. An increased supply of terrigenous particles led to a higher sedimentation rate, which caused oxygen depletion and deterioration in living conditions in the bottom environment. As a result, benthic communities were taxonomically impoverished and commonly consisted exclusively of juvenile forms.

In contrast, during higher sea-level phases flooding of shore areas resulted in a shift of the source area, leading to weakening of the intensity of terrestrial in- flux. This made the reduction in salinity of the surface waters less pronounced (more diverse phytoplankton appeared), and resulted in a lower sedimentation rate. In consequence, higher oxygen availability and a sufficient food supply created better living conditions at the bottom. Such conditions were favourable for the appearance of concretion layers

\section{Acknowledgements}

We would like to thank the peer reviewers, Michał Zaton (Sosnowiec, Poland) and Attila Vörös (Budapest, Hungary), as well as the AGP editor, Ireneusz Walaszczyk (Warsaw), for careful reading of our manuscript and for constructive remarks that improved its final version.

The research of A. Kaim was supported by the Institute of Paleobiology of the Polish Academy of Sciences, a Japan Society for the Promotion of Science (JSPS) Postdoctoral Fellowship for Foreign Researchers, JSPS research grant number 17.05324 (project number 050500000614), and a Polish Ministry of Science and Higher Education research grant N N307 116635, and completed during an Humboldt Fellowship.

\section{REFERENCES}

Boczarowski, A. 2012. Palaeoenvironmental interpretation of echinoderm assemblages from Bathonian ore-bearing clays at Gnaszyn (Kraków-Silesia Homocline, Poland). Acta Geologica Polonica, 62 (3), 351-366.

Dadlez, R. 1989. Epikontynentalne baseny permu i mezozoiku w Polsce. Kwartalnik Geologiczny, 33, 175-198.

Dayczak-Calikowska, K. 1997. Jura środkowa. Sedymentacja, paleogeografia i paleotektonika. In: S. Marek and M. Pajchlowa (Eds), Epikontynentalny perm i mezozoik w Polsce. Prace Państwowego Instytutu Geologicznego, 153, 269-282.

Dayczak-Calikowska, K. and Moryc W. 1988. Evolution of sedimentary basin and palaeotectonics of the Middle Jurassic in Poland. Kwartalnik Geologiczny, 32, 117136. [In Polish with English summary]

Dudek, T. 2012. Clay minerals as palaeoenvironmental indicators in the Bathonian (Middle Jurassic) ore-bearing clays from Gnaszyn, Kraków-Silesia Homocline, Poland. Acta Geologica Polonica, 62 (3), 297-305.

Frakes,L.A.,Francis, J.E. and Syktus, J.I., 1992.Climatemodes of the Phanerozoic. Cambridge UniversityPress, 274pp.

Gedl, P. 2012. Organic-walled dinoflagellate cysts from Bathonian ore-bearing clays at Gnaszyn, Kraków-Silesia Homocline, Poland. Acta Geologica Polonica, 62 (3), 267-280. 
Gedl, P. and Ziaja, J. 2012. Palynofacies from Bathonian (Middle Jurassic) ore-bearing clays at Gnaszyn, Kraków-Silesia Homocline, Poland, with special emphasis on sporomorph eco-groups. Acta Geologica Polonica, 62 (3), 325-349.

Gedl, P., Kaim A., Boczarowski, A., Kędzierski, M., Smoleń, J., Szczepanik, P., Witkowska, M. and Ziaja, J. 2003. Rekonstrukcja paleośrodowiska sedymentacji środkowojurajskich ilów rudonośnych Gnaszyna (Częstochowa) wyniki wstępne. Tomy Jurajskie, 1, 19-27.

Gedl, P., Boczarowski, A., Kaim, A., Kędzierski, M., Leonowicz, P., Smoleń, J., Szczepanik, P. and Witkowska, M. 2006a. Stop B1.5 - Sowa's and Glinski's clay pits (uppermost Bajocian-lowermost Bathonian). Lithology, fossil assemblages and palaeoenvironment. In: A. Wierzbowski, R. Aubrecht, J. Golonka, J. Gutowski, M. Krobicki, B.A. Matyja, G. Pieńkowski and A. Uchman (Eds), Jurassic of Poland and adjacent Slovakian Carpathians. Field trip guidebook of $7^{\text {th }}$ International Congress on the Jurassic System, 151-152. Polish Geological Institute; Warszawa.

Gedl, P., Boczarowski, A., Kędzierski, M., Leonowicz, P., Smoleń, J., Szczepanik, P. and Witkowska, M. $2006 \mathrm{~b}$. Stop B1.6 - Leszczyński's clay pit (Lower Bathonian). Lithology, fossil assemblages and palaeoenvironment. In: A. Wierzbowski, R. Aubrecht, J. Golonka, J. Gutowski, M. Krobicki, B.A. Matyja, G. Pieńkowski and A. Uchman (Eds), Jurassic of Poland and adjacent Slovakian Carpathians. Field trip guidebook of $7^{\text {th }}$ International Congress on the Jurassic System, 153-154. Polish Geological Institute; Warszawa.

Gedl, P., Boczarowski, A., Dudek, T., Kaim, A, Kędzierski, M., Leonowicz, P., Smoleń, J., Szczepanik, P., Witkowska, M. and Ziaja, J. 2006c. Stop B1.7 — Gnaszyn clay pit (Middle Bathonian-lowermost Upper Bathonian). Lithology, fossil assemblages and palaeoenvironment. In: A. Wierzbowski, R. Aubrecht, J. Golonka, J. Gutowski, M. Krobicki, B.A. Matyja, G. Pieńkowski and A. Uchman (Eds), Jurassic of Poland and adjacent Slovakian Carpathians. Field trip guidebook of $7^{\text {th }}$ International Congress on the Jurassic System, 155-156. Polish Geological Institute; Warszawa.

Hallam, A., 1984. Continental humid and arid zones during the Jurassic and Cretaceous. Palaeogeography, Palaeoclimatology, Palaeoecology, 47, 195-223.

Hallam, A., 1985. A review of Mesozoic climates. Journal of the Geological Society, London, 142, 433-445.

Kaim, A. 2011. Non-actualistic wood-fall associations from Middle Jurassic of Poland. Lethaia, 44, 109-124.

Kaim, A. 2012. Faunal dynamics of gastropods in the Bathonian (Middle Jurassic) ore-bearing clays at Gnaszyn, Kraków-Silesia Homocline, Poland. Acta Geologica Polonica, 62 (3), 367-380.

Kaim, A. and Sztajner, P. 2012. Faunal dynamics of bivalves and scaphopods in the Bathonian (Middle Jurassic) orebearing clays at Gnaszyn, Kraków-Silesia Homocline, Poland. Acta Geologica Polonica, 62 (3), 381-395.

Kędzierski, M. 2012. Calcareous nannoplankton from the Bathonian (Middle Jurassic) ore-bearing clays at Gnaszyn, Kraków-Silesia Homocline, Poland. Acta Geologica Polonica, 62 (3), 439-461.

Leonowicz, P. 2012. Sedimentology and ichnology of Bathonian (Middle Jurassic) ore-bearing clays at Gnaszyn, Kraków-Silesia Homocline, Poland. Acta Geologica Polonica, 62 (3), 281-295.

Majewski, W. 2000. Middle Jurassic concretions from Częstochowa (Poland) as indicators of sedimentation rates. Acta Geologica Polonica, 50, 431-439.

Malchus, N. and Steuber, T. 2002. Stable isotope records (O, C) of Jurassic aragonitic shells from England and NW Poland: palaeoecologic and palaeoenvironmental implications. Geobios, 35, 29-39.

Marynowski, L., Otto, A., Zatoń, M., Phillipe, M. and Simoneit, B.R. 2007a. Biomolecules preserved in ca. 168 million year old fossil conifer wood. Naturwissenschaften, 94, 228-236.

Marynowski, L., Zaton, M., Simoneit, B. R.T., Otto, A., Jędrysek, M.O., Grelowski, C., and Kurkiewicz, S. 2007b. Compositions, sources and depositional environments of organic matter from the Middle Jurassic clays of Poland. Applied Geochemistry 22, 2456-2485.

Marynowski, L., Philippe, M., Zaton, M. and Hautevelle, Y. 2008. Systematic relationships of the Mesozoic wood genus Xenoxylon: an integrative biomolecular and palaeobotanical approach. Neues Jahrbuch für Geologie und Paläontologie, Abhandlungen, 247, 177-189.

Matyja, B.A. and Wierzbowski, A. 2000. Ammonites and stratigraphy of the uppermost Bajocian and Lower Bathonian between Częstochowa and Wieluń, Central Poland. Acta Geologica Polonica, 50, 191-209.

Matyja, B.A. and Wierzbowski, A. 2003. Biostratygrafia amonitowa formacji częstochowskich iłów rudonośnych (najwyższy bajos-górny baton) z odsłonięć w Częstochowie. Tomy Jurajskie, 1, 3-6.

Matyja, B.A. and Wierzbowski, A. 2006. Field Trip B1 Biostratigraphical framework from Bajocian to Oxfordian. Stop B1.7 - Gnaszyn clay pit (Middle Bathonian lowermost Upper Bathonian). In: A. Wierzbowski, R. Aubrecht, J. Golonka, J. Gutowski, M. Krobicki, B.A. Matyja, G. Pieńkowski and A. Uchman (Eds), Jurassic of Poland and adjacent Slovakian Carpathians. Field trip guidebook of $7^{\text {th }}$ International Congress on the Jurassic System, 154-155. Polish Geological Institute; Warszawa.

Merta, T. and Drewniak A. 1998. Lithology and depositional environment of the Bathonian clays. In: N. E. Poulsen, J. Bojesen-Koefoed, A. Drewniak, E. Glowniak, J. Ineson, B. A. Matyja, T. Merta and A. Wierzbowski 
(Eds), Mellem-Øvre Jura i Polen. EEP-1995 projekt: Det polske Mellem-Øvre Jura Epikratoniske Bassin, Stratigrafi, Facies og Bassin Historie. Program Østeuropa. Danmarks og Grønlands Geologiske Undersøgelse Rapport 1998/14, 25-41.

Philippe, M. and Thévenard, F. 1996. Repartition and palaeoecology of the Mesozoic wood genus Xenoxylon: palaeoclimatological implications for the Jurassic of Western Europe. Review of Palaeobotany and Palynology, 91, 353-370.

Philippe, M., Barbacka, M., Gradinaru, E., Iamandei, E., Iamandei, S., Kázmér, M., Popa, M., Szakmány, G., Tchoumatchenco, P. and Zatoń, M. 2006. Fossil wood and Mid-Eastern Europe terrestrial palaeobiogeography during the Jurassic-Early Cretaceous interval. Review of Palaeobotany and Palynology, 142, 15-32.

Ratajczak, T. 1998. Hałdy po górnictwie rud żelaza w regionie częstochowskim - stan aktualny i możliwości zagospodarowania, 1-92. Wydawnictwo Instytutu Gospodarki Surowcami Mineralnymi i Energią PAN; Kraków.

Rees, J. 2012. Palaeoecological implications of neoselachian shark teeth from the Bathonian (Middle Jurassic) orebearing clays at Gnaszyn, Kraków-Silesia Homocline, Poland. Acta Geologica Polonica, 62 (3), 397-402.

Shepard, F.P. 1954. Nomenclature based on sand-silt-clay ratios. Journal of Sedimentary Petrology, 24, 151-158.

Smoleń, J. 2012. Faunal dynamics of foraminifer assemblages in the Bathonian (Middle Jurassic) ore-bearing clays at Gnaszyn, Kraków-Silesia Homocline, Poland. Acta Geologica Polonica, 62 (3), 403-419.

Szczepanik, P. 2006. Pyritization of the biogenic remains in the Middle Jurassic dark sediments of the Kraków-Częstochowa Upland. Unpublished $\mathrm{Ph}$. D. thesis. Institute of Geological Sciences, Jagiellonian University, Kraków, Poland.

Szczepanik, P., Witkowska, M. and Sawłowicz, Z. 2007. Geochemistry of Middle Jurassic mudstones (KrakówCzęstochowa area, southern Poland): interpretation of the depositional redox conditions. Geological Quarterly, $51,57-66$.
Wierzbowski, H. and Joachimski, M. 2007. Reconstruction of late Bajocian-Bathonian marine palaeoenvironments using carbon and oxygen isotope ratios of calcareous fossils from the Polish Jura Chain (central Poland). Palaeogeography, Palaeoclimatology, Palaeoecology, 254, 523-540.

Witkowska, M. 2005. Ferruginous carbonate concretions in the Middle Jurassic mudstones from Gnaszyn near Częstochowa (S Poland). Przeglad Geologiczny, 53, 797. [In Polish with English summary]

Witkowska, M. 2012. Palaeoenvironmental significance of iron carbonate concretions from the Bathonian (Middle Jurassic) ore-bearing clays at Gnaszyn, Kraków-Silesia Homocline, Poland. Acta Geologica Polonica, 62 (3), 307-324.

Zatoń, M. and Marynowski, L. 2004. Konzentrat-Lagerstätte-type carbonate concretions from the uppermost Bajocian (Middle Jurassic) of the Częstochowa area, SW Poland. Geological Quarterly, 48, 339-350.

Zaton, M. and Marynowski, L. 2006. Ammonite fauna from uppermost Bajocian (Middle Jurassic) calcitic concretions from the Polish Jura - biogeographical and taphonomical implications. Geobios, 39, 426-442.

Zaton, M., Villier, L. and Salamon, M.A. 2007. Signs of predation in the Middle Jurassic of south-central Poland: evidence from echinoderm taphonomy. Lethaia, 40, 139_ 151.

Zatoń, M., Barbacka, M., Marynowski, L. and Krzystanek, J. 2006. Sagenopteris (Caytoniales) with its possibile preserved biomarkers from the Bathonian of the Polish Jura, south-central Poland. Neues Jahrbuch für Geologie und Paläontologie Monatshefte, 7, 385-402.

Zatoń, M., Machocka, S., Wilson, M.A., Marynowski, L. and Taylor, P.D. 2011. Origin and paleoecology of Middle Jurassic hiatus concretions from Poland. Facies, 57, 275-300.

Ziegler, P.A. 1988. Evolution of the Arctic-North Atlantic and the Western Tethys. American Association of Petroleum Geologists, Memoir, 43, 1-196. 